\title{
Respectable Subjects: The Commonwealth Caribbean Seasonal Agricultural Workers Program in Postcolonial Context
}

by

James Braun

A thesis submitted to the Faculty of Graduate and Postdoctoral Affairs in partial fulfillment of the requirements for the degree of

Master of Arts

in

Political Economy

Carleton University

Ottawa, Ontario

(C) 2012, James Braun 
Library and Archives

Canada

Published Heritage

Branch

395 Wellington Street

Ottawa ON K1A ON4

Canada
Bibliothèque et

Archives Canada

Direction du

Patrimoine de l'édition

395 , rue Wellington

Ottawa ON K1A ON4

Canada
Your file Votre référence

ISBN: 978-0-494-93634-4

Our file Notre référence

ISBN: $978-0-494-93634-4$
NOTICE:

The author has granted a nonexclusive license allowing Library and Archives Canada to reproduce, publish, archive, preserve, conserve, communicate to the public by telecommunication or on the Internet, loan, distrbute and sell theses worldwide, for commercial or noncommercial purposes, in microform, paper, electronic and/or any other formats.

The author retains copyright ownership and moral rights in this thesis. Neither the thesis nor substantial extracts from it may be printed or otherwise reproduced without the author's permission.
AVIS:

L'auteur a accordé une licence non exclusive permettant à la Bibliothèque et Archives Canada de reproduire, publier, archiver, sauvegarder, conserver, transmettre au public par télécommunication ou par l'Internet, prêter, distribuer et vendre des thèses partout dans le monde, à des fins commerciales ou autres, sur support microforme, papier, électronique et/ou autres formats.

L'auteur conserve la propriété du droit d'auteur et des droits moraux qui protege cette thèse. $\mathrm{Ni}$ la thèse ni des extraits substantiels de celle-ci ne doivent être imprimés ou autrement reproduits sans son autorisation.
In compliance with the Canadian Privacy Act some supporting forms may have been removed from this thesis.

While these forms may be included in the document page count, their removal does not represent any loss of content from the thesis.
Conformément à la loi canadienne sur la protection de la vie privée, quelques formulaires secondaires ont été enlevés de cette thèse.

Bien que ces formulaires aient inclus dans la pagination, il n'y aura aucun contenu manquant. 


\section{Abstract}

Drawing on postcolonial theory and informed by a governmentality framework, I argue that the Caribbean Commonwealth Seasonal Agricultural Workers Program (CSAWP) is not only a solution to "structural" labour problems, but also a tool of population management. The program aims to discipline the rural underclass into "respectable" subjects adhering to normative ideas of work, property and family.

Canada's role in the program is that of neocolonial patron; it facilitates the creation of "respectable subjects" as a recipient of Caribbean labour and serves as a 'role model' for development. Imagining itself in the 1960s as the inheritor of British responsibilities in the Caribbean, the decision to admit migrants from Jamaica was an assumption of paternalistic obligations to assist in managing the 'surplus' population. As such, the CSAWP is an expression of interlocking colonial processes between Canada and Jamaica, and the Jamaican government and its citizens. 


\section{Acknowledgements}

The intellectual and emotional debts I have accrued over the course of my research go well beyond the space I have allotted here. I would like to thank Dorienne Rowan-Campbell for establishing contacts and watching over me in Jamaica, and to the men who generously shared their experience of the CSAWP with me. I owe many thanks to Adrian A. Smith, who provided crucial early advice regarding my theoretical framework, and pointed me to some important sources. I am also indebted to him for bringing together the Migration and Development Working Group at Carleton. Lively and fruitful discussions with Adrian and the other members of the working group, Eloy Rivas and Christopher Miller, informed my thinking at an important formative stage.

Thanks to the Ontario Ministry of Training, Colleges and Universities for their support of my program, and to Carleton University's Faculty of Graduate and Postdoctoral Affairs and the Carleton Graduate Student's Association for making it possible to do my fieldwork. Thank you to my cohort at the Institute of Political Economy, but particularly to Kritee Ahmed and Alicia Baker for continually supporting, challenging and teaching me. I owe a great debt of gratitude to my supervisor, Laura Macdonald, and my committee member, Christina Gabriel. I owe very special thanks to Terri O'Neill, who was there every day.

I would like to dedicate this work to my daughter Evie, who inspired everything. 
Table of Contents

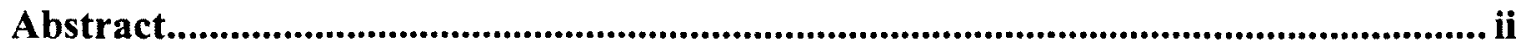

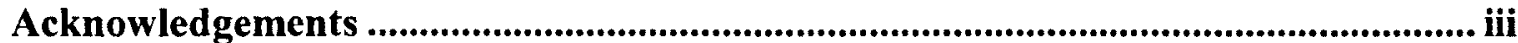

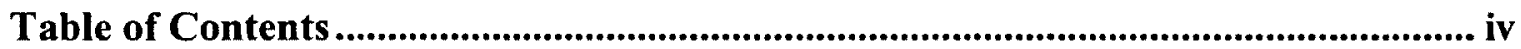

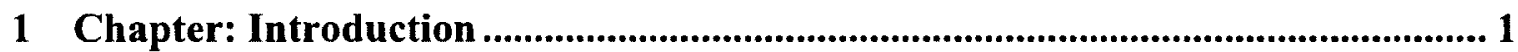

2 Chapter: New Approaches to the Political Economy of Migration ..................... 12

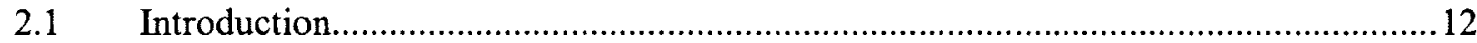

2.2 Traditional Approaches: Marx and Beyond..................................14

2.3 The Opportunities and Limitations of Postcolonial Theory $\ldots \ldots \ldots \ldots \ldots \ldots \ldots \ldots \ldots \ldots \ldots \ldots \ldots$

2.4 Shifting the Register: (Post)colonial Governmentality..........................30

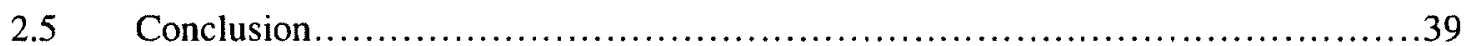

3 Chapter: "I Going Away, I Going Back": A Brief History of Jamaican Labour

Migration, 1838-1966..........................................................40

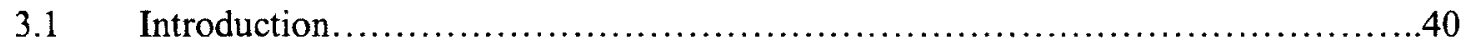

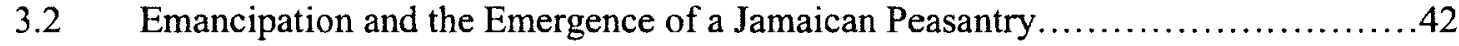

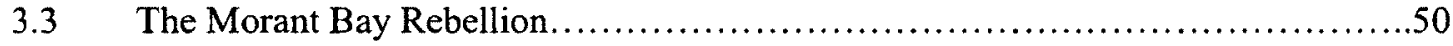

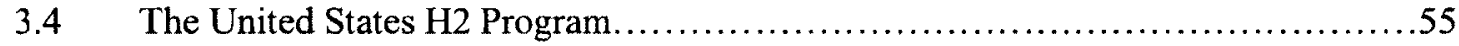

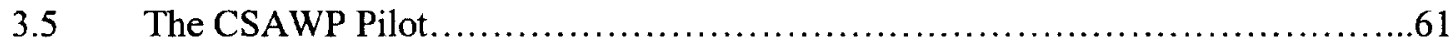

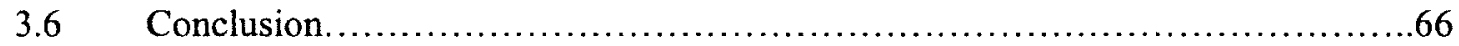

\section{Chapter: Canada-Caribbean Transformations: Migration, Neocolonialism and}

Development................................................................69

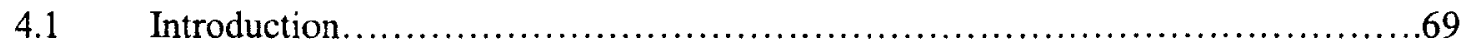

4.2 The Conference in Existing Scholarship.................................. 71 
4.3 The Conference: Neocolonialism and Development.............................77

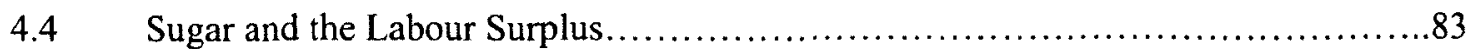

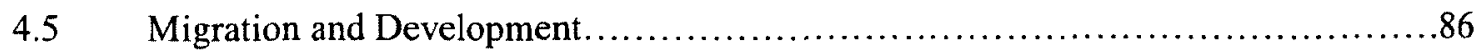

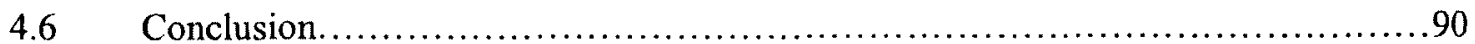

5. Chapter: Jamaica, The Developmentalist State.............................92

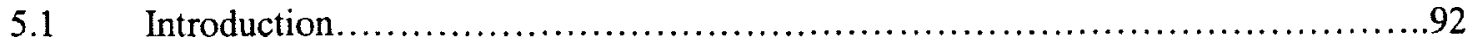

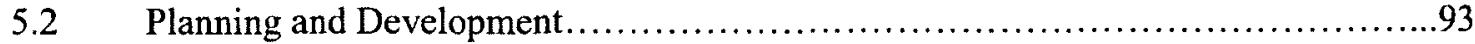

5.3 The OEP and the Formation of "Respectable Subjects" ........................100

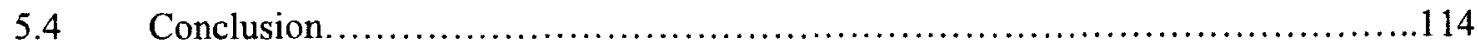

6. Chapter: Conclusion.....................................................116

Bibliography...................................................................121 


\section{Chapter: Introduction}

In September 2000, a revelatory encounter took place on a tobacco and apple farm in Southern Ontario. Jamaican Labour Minister Donald Buchanan, on his first tour of Canadian farms since assuming the portfolio, met with and paid tribute to one of the Canadian Farm Work Program's (CFWP) "stalwarts." Beresford Crumbie was part of the first cohort of farm workers to migrate from Jamaica in 1966 . Now 72 years old, he was in the midst of his 34th seasonal trip to and from Canada, to harvest apples and tobacco at Cunningham Farm. Together with the Jamaican High Commissioner, senior public servants and representatives of Jamaica's two major industrial unions, Buchanan praised Crumbie's long service and spoke to workers and media about the shared obligations of workers and farmers participating in the program: "We expect that while you're here, you'll be properly treated and equally we expect that you are going to give full value to the employers for the pay they are providing you."

In April 2011, controversy erupted in Jamaica over the treatment of farm workers in Canada. The Canadian Medical Association Journal (CMAJ) published a study by Kerry Preibisch and Jenna Hennebry on health issues affecting migrant workers which blamed harsh work conditions and poor safety standards on Canadian farms. The article provoked a defensive response from officials in both Canada and Jamaica. ${ }^{2}$ Pearnal Charles, who took over as Jamaican Labour Minister in 2007, denied any knowledge of poor working conditions in Canada and questioned the objectivity of the report. ${ }^{3}$ Ken

1 "72-Year-Old Farm Worker Still Going Strong in Canada", The Jamaica Gleaner, September 6, 2000.

2 Kerry Preibisch and Jenna Hennebry, "Temporary Migration, Chronic Effects: The Health of International Migrant Workers in Canada" Canadian Medical Association Journal 2011 183(9): 10331038.

3 "Charles to Respond to Canada Farmwork Programme Study,"Jamaica Observer, April 21, 2011; Laura 
Forth, President of the Foreign Agricultural Resources Management Services (FARMS), which administers the program for Canadian farmers, offered a broader condemnation of Canadian scholarship during a telephone interview with the Jamaica Gleaner:

"Universities in Canada don't write one good thing, not one good thing." ${ }^{4}$ Jamaican media were able to substantiate some claims of worker mistreatment; Jamaican officials responded with an investigation into a single farm in Simcoe, an apparent attempt to create a particular scapegoat for what Preibisch and Hennebry, among others, have noted are systemic abuses. ${ }^{5}$

Both of these moments illustrate key aspects of the CFWP, part of Jamaica's Overseas Employment Program (OEP) and known in Canada as the Caribbean Commonwealth Seasonal Agricultural Workers Program (CSAWP). They are illustrative of the ongoing public interest and contestation of the program in Jamaica: both national newspapers regularly report on the program, including incidents involving workers abroad, and negotiations between the Jamaican and Canadian governments over various operational details. These stories also shed insight into certain key relationships. The Jamaican government has a crucial role in administering CSAWP. The Jamaican Ministry of Labour is responsible for recruiting and screening workers at home, monitoring work conditions and housing in Canada, and mediating conflicts between workers and farmers as they arise. As the Beresford Crumbie story demonstrates, government representatives present themselves as mediators and worker advocates

Redpath, "A Heartless Boss - Former Farm Worker Claims Inhumane Treatment at Hands of Canadian Employers", Jamaica Gleaner, April 25, 2011.

4 Laura Redpath, "Poor Working Conditions Canada's Shameful Secret", Jamaica Gleaner, April 28, 2011.

5 Laura Redpath, 'Labour Ministry to Probe Canadian Farm," Jamaica Gleaner, April 28, 2011. 
concerned with the fair treatment of all parties. But the April 2011 controversy suggests something altogether different: in crisis, Jamaica's government appeared to side with and uphold the interests of Canadian farmers against its own workers. ${ }^{6}$ This thesis investigates how the Jamaican government negotiates its relationship with seasonal farm workers it places in Canada, and the nature of the power relations that structure that relationship.

Drawing on postcolonial theory and informed by a governmentality framework, I argue that the CSAWP is not only a solution to "structural" labour problems, but also a tool of population management. The programme aims to soothe domestic social tensions and discipline Jamaicans, particularly their rural underclass, into what Anthony Bogues refers to as the "respectable black" subject. ${ }^{7}$ This social project, framed through the language and rationality of 'development', is inherited from the colonial era. The problem of persuading freedpeople to work on Jamaican sugar plantations after the abolition of slavery coincided with a missionary project to 'civilize' and Christianize them. Wage labour was understood at the time as a morally redemptive force that could transform 'savage' Afro-Jamaicans into 'respectable' Europeanized subjects that embraced normative ideas about property, family and civil society. When efforts to create a wage economy in Jamaica foundered, colonial and postcolonial governments turned

6 I am not the first to make this observation. It has also been noted by Leigh Binford, "From Fields of Power to Fields of Sweat: The Dual Process of Constructing Temporary Migrant Labour in Mexico and Canada," Third World Quarterly 2009, 30(3): 510; Tanya Basok, Tortillas and Tomatoes: Transmigrant Mexican Harvesters in Canada, (Montreal and Kingston, McGill University Press, 2002): 112; Laura Macdonald and Christina Gabriel, "Citizenship at the Margins: The Canadian Seasonal Agricultural Worker Program and Civil Society Advocacy", Politics \& Policy 2011, 39(1): 52.

7 Anthony Bogues, "Politics, Nation and Postcolony: Caribbean Inflections" Small Axe, March 2002: 1516. 
increasingly to employment abroad to achieve the same goals. These disciplining effects remain key to Jamaica's embrace of the CSAWP.

Canada's role in this project is that of a neocolonial patron; it facilitates the social project of creating "respectable subjects" as a recipient of Jamaican labour, and serves as a 'role model' in terms of the development project. Imagining itself in the 1960 s as the inheritor of British imperial obligations in the Caribbean, the decision to admit migrant labour from Jamaica (and the Caribbean more generally) was an assumption of paternalistic obligations to assist Caribbean governments in managing 'surplus' populations through the provision of wage labour. As such, the CSAWP is an expression of interlocking colonial processes between Canada and Jamaica, and the Jamaican government and its citizens.

The Seasonal Agricultural Workers Program (SAWP) is a temporary foreign work program that facilitates the movement of labourers from Mexico and the AngloCaribbean for work on Canadian farms. Beginning with a pilot of 263 Jamaican workers in 1966, the program now employs nearly 24000 farm workers annually, drawn from Mexico, Jamaica, Barbados, Trinidad and Tobago, Antigua and Barbuda, Dominica, Grenada, Montserrat, St. Kitts and Nevis, Saint Lucia and St. Vincent and The Grenadines. ${ }^{8}$ Workers are placed on farms in nine provinces, although the vast majority end up in Ontario. They usually perform manual labour in the greenhouse fruit and vegetable sector, tobacco, ginseng, or other labour-intensive crops too fragile for

8 Maxwell Brem, "Migrant Workers in Canada: A Review of the Seasonal Agricultural Worker's Program" Ottawa: North-South Institute, 2006: 2.; Citizenship and Immigration Canada Canada Facts and Figures: Immigration Overview 2010, http://www.cic.gc.ca/english/resources/statistics/menufact.asp, last accessed August 12, 2012: 62 
mechanical harvest. ${ }^{9}$ The SAWP is unique as a foreign worker program in that it exists as a series of bilateral agreements that entrust sending country governments with key roles in recruiting, monitoring work conditions, and advising Canadian officials on the operation of the program. ${ }^{10}$ The Canadian end of the program is managed by the Foreign Agricultural Resource Management Service (FARMS), a non-profit corporation operated by representatives of the commodity groups that hire through the program. ${ }^{11}$

Although CSAWP has attracted its share of scholarly attention, the role of laboursending countries, or the governments in charge of them, has yet to be fully considered. Vic Satzewich's classic book, Racism and the Incorporation of Foreign Farm Labour, is commonly considered the germinal volume of political economy on the subject, and remains an important contribution to our understanding of SAWP. ${ }^{12}$ Satzewich argues that Canadian reliance on foreign labour is the result of capital accumulation processes that draw domestic labour away from agricultural work, abetted by a "cheap food" policy pursued by the state that pressures producers to lower input costs. ${ }^{13}$ The development of "migrant labour" as a category was a state solution to create a labour pool legally restricted from abandoning farm labour for less onerous and better paid work

9 Tanya Basok, Tortillas and Tomatoes: Transmigrant Mexican Harvesters in Canada, (Montreal and Kingston, McGill University Press, 2002): 36,

10 Brem: 8-9; Kerry Preibisch, "Pick-Your-Own-Labour: Migrant Workers and Flexibility in Canadian Agriculture," International Migration Review 2010, 44(2): 410.

11 Foreign Agricultural Resource Management Services website, http://www.farmsontario.ca/index.php last accessed August 18, 2012.

12 Kerry Preibisch and Leigh Binford identified Satzewich (1991) as "a pioneer study", see "Interrogating Racialized Global Labour Supply: An Exploration of the Racial/National Replacement of Foreign Agricultural Workers in Canada", Canadian Review of Sociology and Anthropology 2007, 44(1): 6. See also citations in Adrian A. Smith, "Legal Consciousness and Resistance in Caribbean Seasonal Agricultural Workers", Canadian Journal of Law and Society 2005, 20(2): 95-122; Basok 2002; Harald Bauder, "Foreign Farm Workers in Ontario (Canada): Exclusionary Discourse in the Newsprint Media" Journal of Peasant Studies 2008 35(1): 100-118; Sherrie Larkin, "Workin on the Contract: St Lucian Farmworkers in Ontario, A Study of International Labour Migration" (PhD dissertation, McMaster University, 1998).

13 Satzewich: 81-82. 
elsewhere. ${ }^{14}$ The tacit racialization of Canadian identity (and by extension, its foreign "Other") obscures and excuses the production of exploitative relations through unfree labour. $^{15}$

Tanya Basok nuances this argument in two ways. First, she argues that this type of migrant labour is only structurally necessary for those occupations that depend on unfree labour. ${ }^{16}$ Second, she contends that this labour is attractive to farmers not because it is cheap but because it is unfree. ${ }^{17}$ Migrant labour is a feature of larger, profitable farms that aren't as vulnerable to the cost pressures Satzewich describes, and can be more expensive than domestic labour sources; it is the workers inability to change jobs or refuse the demands of employers that makes them so crucial to the time-sensitive labour of the harvest. Working in a similar theoretical vein, Cindy Hahamovitch's recent book on the history of the $\mathrm{H} 2$ visa program in the US describes the growth of a migrant labour program alongside an already racialized pool of domestic labour. ${ }^{18}$ The desire of farmers, particularly the Florida sugar industry, to use guestworkers in order to discipline the labour demands of domestic workers further demonstrates the complex relationship between race, citizenship and capital accumulation in the development of agricultural labour. ${ }^{19}$

Much of the subsequent literature has built on Satzewich's insight that the construction of the citizen/non-citizen boundary helps to justify particular labour

14 Ibid: 35.

15 Satzewich: 191.

16 Basok, 2002: 14.

17 Ibid: $17,144$.

18 Cindy Hahamovitch, No Man's Land: Jamaican Guestworkers in America and the Global History of Deportable Labour (Princeton University Press, Princeton, 2011).

19 Ibid: 83. 
practices. Examining Ontario media, Harald Bauder notes that migrant workers are presented simultaneously as crucial to local agricultural economies and dehumanized "others" that pose a threat to the order of their host communities. ${ }^{20}$ Kerry Preibisch examines the significant control farmers hold over migrant workers through both the CSAWP and the Low Skill Pilot Project (LSPP), arguing the program's structure makes possible exploitative labour practises that would prove impossible to implement on domestic labourers better protected by Canadian laws and citizenship rights. In particular, farmers can segment the workforce along racial, national and gendered lines, to improve their control and restrict workers' bargaining power. ${ }^{21}$ Tanya Basok uses the experience of Mexican migrants to demonstrate the gap between social citizenship rights granted to migrants on paper, and those actually claimed in practise. She argues that lack of knowledge and social exclusion hinder workers' ability to claim social rights and legal protections upheld for them in law. ${ }^{22}$ Laura Macdonald and Christina Gabriel make a similar observation in their examination of how civil society organizations have stepped into an information gap left by liaison officials from sending countries. ${ }^{23}$ Adrian Smith uses the experience of migrant farm workers to explore issues of legal consciousness, and how workers' understanding of law shapes their resistance to poor work conditions and their assertion of rights. ${ }^{24}$

20 Bauder: 115.

21 Kerry Preibisch, "Pick-Your-Own Labour: Migrant Workers and Flexibility in Canadian Agriculture", International Migration Review 2010, 44(2): 420.

22 Tanya Basok, "Post-national citizenship, social exclusion and migrants rights: Mexican seasonal workers in Canada" Citizenship Studies 2004, 8(1): 61.

23 Laura Macdonald and Christina Gabriel; "Citizenship at the Margins: The Canadian Seasonal Agricultural Worker Program and Civil Society Advocacy", Politics \& Policy 2011, 39(1): 51.

24 Adrian A Smith, "Legal Consciousness and Resistance in Caribbean Seasonal Agricultural Workers," Canadian Journal of Law and Society 2005 
The above literature engages CSAWP within an explicitly national framework. The relationship of the sending country government to its workers is rarely engaged with and never focused on, despite their key role in upholding the vulnerability of their workers. Hahamovitch took the innovative step of interviewing retired liaison officers and examining documents of the Jamaican government, as well as British Colonial Office, to incorporate the sending country perspective into her study. ${ }^{25}$ But while her book illuminates the agency of the Jamaican (and, to a lesser extent, Bahamian and Mexican) officials, it does not ask why government agents defend workers on some grounds but abandons them on others. Their role as worker advocates is mostly taken for granted, even if their ineffectiveness is noted. ${ }^{26}$ Janet McLaughlin includes Jamaican and Mexican public servants in her examination of how various actors "collude and compete to produce the flexible, subaltern ideal migrant worker," but her analysis is confined to subjectivities formed around the worksite in Canada, when clearly sending states have a much broader view, and a more comprehensive reach, into the lives of their citizens. $^{27}$ Satzewich, in discussing why Mexico joined the SAWP program in 1974, urges consideration of the "at times conflicting interests of the host country's bureaucracies, its business community, and the sending countries' representatives influence the formation of policies on seasonal migration programs", but his focus is on articulating the independent interests of Canada's immigration bureaucrats in

25 Hahamovitch: 9-10.

26 Ibid: 84.

27 Janet McLaughlin, "Classifying the 'Ideal Migrant Worker': Mexican and Jamaican Transnational Farmworkers in Canada" Focaal--Journal of Global and Historical Anthropology 57 (2010): 79-94. 
institutionalizing migration. ${ }^{28} \mathrm{He}$ is largely silent on the interests and motivations of the Mexican government in joining the program.

Some literature has emerged on temporary foreign work programs from the perspective of labour-sending countries. A year prior to the publication of Racism and the Incorporation of Foreign Labour, Irving André argued that the origins and persistence of the SAWP lay in the political economy of Caribbean states and their stunted development from corporate imperialism and capital accumulation. ${ }^{29}$ His argument is rooted in a structuralist interpretation of dependency theory, giving scant consideration to any individual or government agency, but it nonetheless represents the most complete attempt to bring sending countries into any understanding of SAWP. More recently, Robyn Magalit Rodriguez examined the Philippines as the archetype of the "labor broker state", actively exporting and marketing its citizens as overseas workers to cope with the socio-economic dislocations of structural adjustment. ${ }^{30}$ Sarah Gammage has made a similar argument regarding El Salvador's policies towards its diaspora in the United States. ${ }^{31}$ David Fitzgerald examines Mexico's reaction to mass emigration since the 1970s, "and how those responses have changed the social contract between emigrants and their home country." ${ }^{32}$ A Nation of Emigrants focuses primarily on long-term, open-ended migration; temporary work programs like CSAWP are not part of his study.

28 Vic Satzewich, "Business or Bureaucratic Dominance in Immigration Policymaking in Canada: Why Was Mexico Included in the Caribbean Seasonal Agricultural Workers Program in 1974?" International Migration and Immigration 2007, 8: 256.

29 Irving André, "The Genesis and Persistence of the Commonwealth Caribbean Seasonal Agricultural Workers Program in Canada", Osgoode Hall Law Journal 1990 28(2): 243-302.

30 Robyn Magalit Rodriguez, Migrants for Export: How the Philippine State Brokers Labor to the World (Minneapolis: University of Minnesota Press, 2010).

31 Sarah Gammage, "Exporting People, Recruiting Remittances: A Development Strategy for El Salvador?" Latin American Perspectives 2006, 33: 75-100.

32 David Fitzgerald, A Nation of Emigrants: How Mexico Manages its Migration (Los Angeles, University of California Press, 2009): 12. 
These works offer, to varying degrees, useful models for studies of migration management. It is surprising, given Jamaica's long history with labour migration and well-established diaspora, that it has been thus far overlooked.

My main methodological task has been to integrate the current operation of CSAWP into an analysis of Jamaica's historical experience with labour migration and colonial government. Drawing primarily on academic historical accounts, I have traced the evolution of Jamaican labour migration as a solution to social, as well as politicaleconomic, problems that begin with the plantation sugar and slave economy of the eighteenth and early nineteenth centuries. Alongside this, I have extended Laura Macdonald's analysis of Canada's involvement in the Anglo-Caribbean to explain the genesis of CSAWP as part of Canada's role within the British imperial system. ${ }^{33}$ Having established this historical background, I turn to a discursive analysis of Jamaican government documents and media to demonstrate the continuity of colonial epistemology in the developmentalist discourses of Jamaican social policy in general, and seasonal labour migration programs in particular.

My primary data comes from three major sources: Canadian historical records from Library and Archives Canada, print articles from Jamaica's major national newspapers, and interviews with Jamaicans previously (but not currently) employed through CSAWP, gathered on a research trip to Kingston December 9-20, 2011. As programme participation is a coveted and precarious privilege, the exclusion of current participants was a conscious methodological choice to limit the vulnerability of my research subjects. The stakes involved for workers was demonstrated to me in the 
interview process. Of the three men I spoke to, none had left the CSAWP voluntarily, nor did any of them have a definite idea of why they were dropped from the programme. To protect their confidentiality, interview participants are not identified by their real names.

My original research plan also included interview and archival evidence from the Jamaican government, but access to these sources proved to be a significant challenge. ${ }^{\mathrm{i}}$ Cindy Hahamovitch has previously noted the difficulties of securing archival records from the Jamaican Ministry of Labour. The conviction of Labour Minister J.A.G. Smith in the 1990s for embezzling from the farm work programme has tightened a culture of secrecy in the civil service; according to Hahamovitch, the ministry regularly burns documents rather than turn them over to the national archives. ${ }^{34}$ While I was unable to speak to government officials directly, their numerous statements to media and publicly available government documents shed invaluable light on the discourses surrounding the program and its participants.

My chapters are organized as follows: in chapter two, I examine Satzewich and André in detail to show how they provide a persuasive but incomplete theory of migration under CSAWP; I then describe how postcolonial theory and governmentality, particularly as they have been applied to Jamaican decolonization, breathes conceptual life into their framework and permits new questions to be asked about temporary labour migration. Chapter three provides an historical analysis of Jamaican labour migration, beginning with the abolition of slavery in 1834 to trace the conceptual construction of Jamaica's "labour surplus," and the development of institutionalized labour migration as a 
solution. I argue that this surplus is not grounded in any "real" political economy of the island. Rather, it came about through an imagining of the island's economic function within the context of the British Empire, and racist discourses about Jamaica's peasant farmers. Chapter four takes up Macdonald's analysis of the imperial ideologies at work in Canadian foreign policy. Through archival analysis of the 1966 Canada-Caribbean Commonwealth Conference, I show how colonial paternalism and Canada's selfconscious identification as the inheritor of empire in the Americas, helped structure Canada's vision for the postcolonial Anglo-Caribbean and their role within it. Although Jamaica was already sending farm workers to Canada through a pilot project, the promise was made at this conference to expand the program to other Anglo-Caribbean countries. The presentation of migration as part of the "aid and trade" agenda of the conference demonstrates how Canada's aid commitments to the Anglo-Caribbean helped aidrecipient territories manage their "surplus" populations. Chapter five examines the operation of the program from the Jamaican end. I demonstrate how the migration program, its ancillary services and public presentation are rooted in a developmentalist problematic of government that echoes historical understandings of the island, its inhabitants, and its place in the world system. 


\section{Chapter: New Approaches to the Political Economy of}

\section{Migration}

\subsection{Introduction}

Most scholarship on CSAWP is conducted within the theoretical frame of Satzewich's Racism and the Incorporation of Foreign Labour, which explains the program as a solution to structural problems in Canada's labour market that creates persistent shortages of agricultural workers. ${ }^{35}$ Satzewich provides a persuasive innovation over previous theories of migration, as demonstrated by his continuing influence; nevertheless, there are limits to what his conceptualization can explain, and the use of this framework has largely confined conversations to the program's operation in Canada and the citizen/non-citizen segmentation of the labour force. Lesser known is Irving André's "The Genesis and Persistence of the Commonwealth Caribbean Seasonal Agricultural Workers Program in Canada", published a year prior to Satzewich, which attempts to explain Caribbean labour migration as the result of structural defects in Caribbean economies that create "permanently high levels of unemployment in the islands." ${ }^{36}$ Their arguments are highly complementary, and it is tempting to read them together as a transnational theory of Caribbean labour migration. ${ }^{37}$

35 See also Satzewich's summary in "Business or Bureaucratic Dominance in Immigration Policymaking in Canada: Why was Mexico Included in the Caribbean Seasonal Agricultural Workers Program in 1974?" International Migration \& Integration 2007, 8: 262-63.

36 Irving André, "The Genesis and Persistence of the Commonwealth Caribbean Seasonal Agricultural Workers Program in Canada", Osgoode Hall Law Journal 1990, 28(2): 246.

37 I am grateful to Adrian Smith, and the meeting of the Migration and Development Working Group in October, 2011, for bringing me in contact with André's article, and presenting it as a complement to 
However, this conceptualization of SAWP does not adequately explain or account for the power relations between Canada and its labour sending countries. As each author examines respective political economies of Canada and Caribbean islands as discrete national (or regional, in André's case) entities, their models do not consider how the world system and their historical positions within it have created and connected the relative labour surpluses and deficits in question. Moreover, both authors take for granted a particular logic of capital accumulation produced within a liberal rationality of government. My argument is that the rationality that structures the relationship between Canada and Jamaica also shapes imaginaries of their respective economies. The Jamaican government's drive to export its citizens is embedded in a particular way of problematizing its citizens and the economy, inherited from colonial rule.

In this chapter, I outline Satzewich and André's arguments and explain in detail the limits of their use in answering my research question. I will then discuss how Fanonian postcolonial critiques of Jamaican decolonization fill in some of the conceptual gaps, explaining the social stratifications of postcolonial Jamaican society, the persistence of exploitative relations and institutions in the postcolony, and the affinity between Jamaican and Canadian elites. Finally, I will explain how Foucault's concept of governmentality can build on postcolonial analyses, engaging primarily with the work of David Scott and Anthony Bogues. A governmentality approach shifts the register of analysis from ideologies or interests to political rationalities and forms of rule. While Canadian and Jamaican policy makers have taken at times conflicting ideological stances, 
an analysis of their shared epistemic lens helps us understand why they cooperate in the exploitation of migrant labour.

\subsection{Traditional Approaches: Marx and Beyond}

Satzewich's theory of the relationship between migration and capitalism builds on the work of earlier Marxist migration theorists: Stephen Castle, Godula Kosack, Heather Booth and Tina Wallace. ${ }^{38}$ Their work on post-war immigration to Western Europe responded to classical "push-pull" theories of migration by proposing a model that instead emphasized processes of capital accumulation and uneven development in the world system. ${ }^{39}$ Castles et al argue that the penetration of capitalist relations of production into Europe's colonial possessions created pools of surplus labour, while postwar reconstruction and the renewal of industrial capacity in Europe created a massive increase in labour demand. The resulting in-migration between 1945 and 1973 was stimulated by the inability of domestic labour reserves to fill European labour shortages. Conversely, western European states restricted in-migration following 1973-74; the result of a recession following oil price spikes, as well as increasing "immigrant" demands on social services and labour organization that undermined their earlier usefulness to capital as a source of cheap labour. ${ }^{40}$ These restrictions, they argue, accompanied a change in state priorities towards family reunification and permanent settlement instead of recruiting temporary "guest workers", which Castles et al "identified as a natural and

38 Satzewich 1991: 15.

39 Ibid: 16.

40 Ibid: $6-8,16-17$. 
'inevitable' feature of the migration process. ${ }^{41}$ The incorporation of immigrant families into European national communities created racially segmented class structures, leading Castles, Booth and Wallace to question the validity of using a solely Marxist class analysis.

Satzewich accepts the approach of these analysts, but he critiques them along three main lines: their underemphasis of the role of the state in controlling immigration, their tendency to homogenize 'the immigrant' as an analytical category, and their abandonment of "the primacy of Marxist class categories" in describing Western European societies. ${ }^{42}$ Satzewich argues that these critiques are based upon a reductionist reading of Marxism that overlooks the ways states intervened to facilitate labour migration after 1945, defining intervention exclusively as the ways states moved to restrict migration following $19733^{43}$

Satzewich responds by classifying the various modes of migrant labour incorporation, based on the status of migrants as 'migrant' or 'immigrant' and 'free' or 'unfree' labour. Migrants are foreign-born people whose relocation is subject to temporal constraints, whereas immigrants are free to relocate on a permanent basis. ${ }^{44}$ Free labour, following Marx, is wage labour "free from relations of direct political and ideological domination which structure and determine for whom they provide surplus labour," whereas unfree labour is brought into production through the use of legal or political compulsion, without the ability to circulate in the labour market. ${ }^{45}$ The maintenance of

41 Ibid: 18.

42 Ibid: 20.

43 Ibid: $21-26$.

44 Ibid: $39-40$

45 Ibid: 41-42. 
these "modes of incorporation" and the sorting of workers necessarily falls under the mandate of the hosting state. ${ }^{46}$ Even in the "laissez-faire" period that Castles et al identify from 1945-1973, states actively intervened to structure the composition and form of migratory waves rather than simply standing aside while capital determined its own imperatives. The "turning point" of 1973 did not reflect new state concerns about foreign-born labour in terms of "political and ideological considerations about the future stability of the nation state," so much as it did changing political objectives within the frame of an already established ideology. ${ }^{47}$

Such ongoing state intervention in migration is necessary, Satzewich argues, by virtue of the function of the state in a capitalist system. The state, he contends, is responsible for "the provision of the conditions for the direct accumulation of capital. It is also structured by the need for the legitimization of the process of capital accumulation," ideological and material imperatives that Satzewich describes as "oftentimes contradictory." ${ }^{48}$ In later work, Satzewich further argues that the political, fief-building, goals of immigration bureaucrats themselves further muddy their role as facilitators of capital accumulation. ${ }^{49}$ These divergent goals are demonstrated in the opening pages of Racism and the Incorporation of Foreign Labour, in his discussion of a debate between bureaucrats in the Department of Citizenship and Immigration over whether to deport immigrants who had been admitted to the country as farm labourers but had abandoned the work earlier than promised, for better employment in other

46 Ibid: 35.

47 Ibid: 18.

48 Ibid: $44-45$.

49 Satzewich 2007: 260. 
industries. ${ }^{50}$ The tension between the need for scarce agricultural labour and the inherent rights of Canadian citizenship suggests a dialectic between the material provision of labour necessary for capital accumulation and the legitimatizing project of nationhood, expressed through a universal right to freely choose work and racially-motivated claims to Canadian citizenship. The solution, Satzewich argues, was the creation of a category of temporary migrant worker, racialized according to a perceived affinity for agricultural labour, and sufficiently outside the imagined Canadian community to be restricted the right to free labour.

Irving André likewise situates his work as a response to classical "push-pull" theories of migration, although his work focuses on the political economy of the labour exporting country as the primary determinant of migration. Drawing on Hilbourne Watson, he argues that emigration is a symptom of the underdevelopment of the Caribbean, and a conscious policy of Caribbean governments to promote economic development within their own countries. Labour migration, he contends, "represents a politically expedient means of avoiding structural reform of the Caribbean economies," and encourages governments to turn a blind eye to worker abuse in host countries. ${ }^{51}$

André describes the political economy of the modern Caribbean as one descended, fundamentally unaltered, from the plantation slavery economy created by European colonization in the eighteenth century. It is characterized by a high degree of foreign ownership which appropriates most of the surplus value produced by local labour, repatriating it to Europe and North America. Multinational "absentee" owners who exert monopoly power over the islands and are compelled to shed labour in order to maintain

50 Satzewich 1991: 1-2.

51 André: 244-246. 
cheap exports have little incentive to invest in the development of local economies. The surplus value that would ordinarily be re-invested by the local bourgeoisie is mostly repatriated to foreign shareholders. The result is the growth of a pool of "surplus" labour driven to seek employment abroad, facilitated and encouraged by domestic governments. $^{52}$

Satzewich's commentary on Castles et al applies to André as well. While André retains a class-based analysis, his reading of the Caribbean state follows Castle's et al's rigid economism. The colonial state, through the production and application of law, is described as "the handmaiden of the beneficiaries of commercial capitalism," suggesting a clear role in facilitating the material conditions of capital accumulation without much attention to sustaining its legitimacy. ${ }^{53}$ Modern Caribbean governments, André contends, have little control over the migration processes they participate in to promote economic development. ${ }^{54}$ While there can be little doubt that power relations between Canada and Caribbean states limit Caribbean agency in managing the program, André's argument is overdeterministic. If international capital can discipline Caribbean governments so ruthlessly, one is left to wonder how they negotiate Satzewich's dialectical relationship between capital accumulation and national legitimacy. Caribbean governments possess their own national projects, and require a degree of consent from their own populations to enact them. An argument that these states are completely beholden to capital accumulation needs to explain how national legitimacy is maintained. André is ambivalent about whether Caribbean governments participate willingly in the

52 Ibid: $253-255$.

53 Ibid: 248.

54 Ibid: 292. 
exploitation of their workers, or are straitjacketed by the circumstances of the Caribbean political economy. ${ }^{55}$ This is an ambiguity that glosses over the social stratifications of Jamaican society, and leaves open a number of questions about the agency and consent of Caribbean workers and governments.

Just as Castles et al homogenize 'the immigrant', André's dependency theory model homogenizes 'the emigrant'. Although his work is focused on a single migration program, his analysis fails to acknowledge the varied conditions of Jamaican migration and the domestic social stratifications that accompany it.

Robyn Magalit Rodriguez's formulation of the "labor broker state" approaches a reconciliation of Satzewich and André. ${ }^{56}$ Labour brokerage, she argues, is a conscious state policy of facilitating the temporary out-migration of citizens to work abroad, harnessing remittance incomes through the banking system and state-sponsored development projects. ${ }^{57}$ She, like Satzewich, situates this policy within the competing state objectives of facilitating capital accumulation and national legitimacy: using the Philippines as an archetype, she argues that this is a strategy for the Filipino government to manage the social dislocations that accompanied neoliberal restructuring. ${ }^{58}$ Moreover, the government's motivation is not strictly economic; by finding overseas employment for workers, the government is also managing social unrest and breaking up potential political dissent. ${ }^{59}$ Unlike Andrềs essentially passive labour-sending state, the labour

55 See, for example, pp. 246, 292.

56 Once again, I am indebted to Adrian A. Smith and the Migration and Development Working Group for bringing Rodriguez to my attention, and illuminating her role as a way of reconciling Satzewich and André.

57 Robyn Magalit Rodriguez, Migrants for Export: How the Philippine State Brokers Labor to the World (Minneapolis, University of Minnesota Press, 2010): $\mathrm{x}$.

58 Ibid: xviii

59 Ibid: 142 . 
broker actively negotiates with receiving states to market its workforce abroad, and to shape relationships with its worker-citizens to maintain their ties to home and encourage remittance flows. But where Rodriguez's analysis falls flat, at least in the Caribbean, is her contention that labour brokerage is a specific manifestation of neoliberalism. The Caribbean, and Jamaica in particular, have histories of institutionalized "migration management" that predate the neoliberal turn, as we shall see later.

Read side-by-side, Satzewich and André link Canadian and Caribbean political economies into a single dynamic of (under)development and capital accumulation: labour surplus meets labour shortage. It is less useful in explaining how Canada and the Caribbean came to occupy their relative positions in the world system, or why Canada wields so much power in this arrangement. R.G Cecil and G.E. Ebanks, for example, argue that CSAWP constitutes a form of reverse colonialism, where "West Indian islands are able to map and earmark part of Ontario as adjunct economic spaces." ${ }^{60}$ This is a functionalist assessment of the program that is difficult to sustain empirically, but it demonstrates that the power relations within the CSAWP are not necessarily self-evident. There is no prima facie reason why an economy facing persistent labour shortages should hold particular power over an economy with persistent labour surpluses.

Moreover, the mere presence of national labour shortages and labour surpluses does not necessarily explain or guarantee that states will come together to address them. At the same time the CSAWP was first negotiated, Forbes Burnham was attempting to encourage migrants of Afro-Caribbean descent to settle on over a million acres in

60 R.G. Cecil and G.E. Ebanks, "The Caribbean Migrant Farm Worker Programme in Ontario: Seasonal Expansion of West Indian Economic Spaces" 
Guyana's interior. ${ }^{61}$ The scheme attracted little interest from Caribbean governments. ${ }^{62}$ The reasons for their reluctance have not been made explicit, but it is reasonable to speculate that Guyana's violent interethnic politics played a role. ${ }^{63}$ Mistrust over Burnham's ambitions for a unitary Caribbean state likely also contributed. ${ }^{64}$ The key point is that national labour surpluses and deficits do not seek each other out independently of political or social considerations. The relationship between Canada and the Caribbean is shaped through the sedimented histories of these regions and ideologies of race, labour and capital, which all find expression in programs such as the CSAWP.

\subsection{The Opportunities and Limitations of Postcolonial Theory}

Both Satzewich and André stress the importance of an historical analysis in understanding temporary migration programs as an outcome to political-economic processes. ${ }^{65}$ But while both analyses situate Canada and the Caribbean within the capitalist world system, neither considers how these states developed in tandem, bound by common economic, political and ideological ties. Canada and the Anglo-Caribbean postcolonies are each creations of the British imperial legacy, and their relations, as well as their respective political economies, were shaped through their historical positions as part of the empire. A thorough historical analysis of labour migration from the Caribbean needs to take this history into account.

61 LAC, J.R. McKinney, "Impressions of West Indian Leaders and Their Attitudes Towards the Conference", June 10, 1966, RG25 vol 9123, File 20-4-CCCC-1 vol. 1: 1.

62 LAC, "Press Conference: Commonwealth Caribbean-Canada Conference" July 7, 1966 MG25 N 40 , File July 1966: 5 .

63 Steve Garner, Guyana 1838-1985: Ethnicity, Class \& Gender (Kingston: Ian Randle Publishers, 2008): 125.

64 LAC, "Press Conference: Commonwealth Caribbean-Canada Conference" July 6, 1966 MG25 N 40, File July 1966: 6 .

65 Andre: 244; Satzewich 1991: 53. 
Postcolonial theory offers a helpful paradigm to approach such a history. Robert C. Young describes postcolonialism as an investigation of "[European colonialism's] contemporary effects in western and tricontinental cultures, making connections between that past and the politics of the present." ${ }^{66}$ It is a theory of history that explains our present as the legacy of European efforts to remake the world in its own image in the eighteenth and nineteenth centuries; the politics of our time are defined largely by attempts to challenge the European project. ${ }^{67}$ Henry Schwarz defines it as an interdisciplinary "study in the West of the cultures and contexts of decolonization," but a study which challenges the forms and categories of 'Western' knowledge production. ${ }^{68}$ Macdonald describes postcolonialism as a relatively successful fusion of Marxist materialism with postmodern and poststructuralist critiques of modernity and its associated forms of knowledge. ${ }^{69}$ These definitions each capture postcolonialism's emphasis on questions of political and economic domination, and the power imbalances between 'the West' and its previously colonized regions. In that sense it is fully compatible with Satzewich and André's investigations of capital accumulation on a global scale. But postcolonialism also explores how both European and previously colonized imaginations are shaped by the imposition of modern structures and ideologies. Certain schools of postcolonial thought provide an argument that the political economies of Caribbean states (and Canada) are constructs of European colonialism and, as such, tools for the perpetuated domination of 'the West'.

66 Robert C Young, Postcolonialism: An Historical Introduction (Maden MA, Blackwell, 2001): 6 67 Ibid: 5.

68 Henry Schwarz, "Mission Impossible: Introducing Postcolonial Studies in the US Academy" in Henry Schwarz and Sangeeta Ray (eds) A Companion to Postcolonial Studies (Malden, MA: Blackwell Publishing, 2005): 6.

69 Macdonald: 113. 
Edward Said and Frantz Fanon are generally acknowledged as the founders of postcolonial thought. In Orientalism, Edward Said developed a highly influential account of the western imagination of the "Orient", a set of discourses that defines a European (and, more recently, American) "Occident" against an exoticized "Other". This dichotomy is both epistemological and ontological; the "Oriental" is imagined to have a mode of thought and internally cohesive worldview all its own, and the relation between these spheres is presumed to be one of "Occidental" strength. ${ }^{70}$ Both a product of and a justification for Euro-American colonialism, Orientalist discourse defines the "backward", "irrational", decadent" Orient as a foil for the "rational," "progressive," "industrious" West, reifying Western cultural values as metrics for the comparative weaknesses of the East. ${ }^{71}$ Said's principal contribution is an interrogation of 'Western' knowledge production, particularly in reference to the colonized, and the ways that knowledge production reproduces an ideology of 'Western' superiority. As Macdonald has argued, this ideology and the experience of empire shaped and continues to shape Canada's imagination of itself and the global south. ${ }^{72}$

Frantz Fanon's classic work The Wretched of the Earth deals more closely with the physical and political subordination of colonized peoples. Asserting that "it is the colonist who fabricated and continues to fabricate the colonized subject," Fanon argues that the process of decolonization is conducted according to the values and structures imposed by colonial regimes. ${ }^{73}$ Brokered by a national bourgeoisie with a metropolitan education and mobilizing through modern (European) notions of statehood, political

70 Edward Said, Orientalism (New York: Vintage, 1979): 40.

71 Ibid: 31-35.

72 Macdonald: 113.

73 Frantz Fanon, The Wretched of the Earth (New York: Grove Press, 2004 [1963.): 2. 
parties and urban, industrial capitalism, mass demands for liberation and equality are coopted into a movement for independent political and social structures that largely reproduce the colonial regime. Under these conditions, the post-colonial project continues to impose a European-conceived modernity on hinterlands of the postcolony. ${ }^{74}$ Fanon`s work substantially predates Said`s but anticipates him in important ways. The "imitation" of European values and systems of knowledge in the postcolony reproduces the unequal power relations produced within them, privileging the 'Western' over indigenous knowledge production and giving 'rational' credence to the old economic and political structures of colonial domination. In attempts to remake themselves more fully in the metropolitan image, the postcolony is a continuation of the colonial project in local hands.

A rich literature interrogating postcolonial Caribbean society and politics substantially echoes Fanon's analysis. Percy Hintzen argues that anti-colonial projects organized in the Caribbean have failed to bring about promised political and economic transformation after having expelled European colonizers; rather, "colonialism has been replaced by even more egregious forms of domination, super-exploitation and dependency." ${ }^{75}$ The stumbling block, he contends, is the afro-Creole nationalist ideology through which ascendant local elites organized and mobilized anti-colonial movements. Cultural appeals to a shared afro-Creole identity conflated the struggles of economic justice and racial equality, and obscured class differences between an educated "middle strata" and African-descended working class. The symbolic appeals of nationhood,

74 Ibid: $64-65$.

75 Percy Hintzen, "Reproducing Domination and Legitimacy Constructs in the West Indies" Social Identities: Journal for the Study of Race, Nation and Culture 1997, 3(1): 48. 
mobilized through discourses of development and sovereignty, protected the middle strata's access to economic and state institutions by virtue of their administrative and technical knowledge. The articulation of the postcolonial state through such familiar institutions as Westminster parliament, and an ideology of 'development' predicated on the metropolitan model of consumer capitalism, both consolidated the ascendant elite's status as managers of the postcolonial state and bolstered international "relationships of affinity with dominant class actors internationally, particularly those in the northern industrial countries. ${ }^{76}$

Anthony Bogues fashions a similar critique. The principal aim of Afro-Creole politics, he argues, was to transfer political power to Jamaicans through essentially the same institutional structure created by the colonial elite. ${ }^{77}$ Significantly, Bogues notes, the Afro-Creole critique focuses on colonialism as the root of injustice, ignoring the period of racial slavery that shaped the Caribbean economy and political structure. ${ }^{78}$ Rather than mounting a challenge to the inequalities inherent to political and economic structures of the colonial state, Afro-Creole nationalism articulated its anti-colonial demands in a language of tutelage and development based on metropolitan models: "We are ready for self-government because we are Western. ${ }^{179}$ The parallels with Fanon's narrative are clear.

Obika Gray and Aaron Kamugisha have each used this critique of Afro-Creole nationalism to analyze the social stratifications of Jamaica post-independence. Gray concerns himself with explaining the apparent resilience of Jamaica's political structure 
despite overwhelming evidence of economic failures and social and political abuses. The political elite has, Gray argues, brought the masses significant forms of social power through political independence and recognition within the Creole nationalist project, and yet denies them "politically relevant forms of citizenship." ${ }^{80}$ Politics in Jamaica are played out in a peculiar fusion of democratic forms and clientelist relationships that Gray styles "predatory power," a form of elite dominance that appropriates and assimilates cultural tendencies of the masses in the maintenance of elite hegemony. ${ }^{81}$ This manifests itself in a sort of political theatre where "light-skinned middle class party leaders....exhibited street-based moralities. They copied the vernacular culture of the working and the unemployed lower class supporters and mimicked the 'nation language' of downtrodden groups. ${ }^{82}$ In this political climate, the "garrison towns" run by partyaffiliated gangsters proliferate while leaders simultaneously "[demonize] the protesting poor as criminals and threats to public order." 83

Kamugisha reflects on the "implosion of radical attempts to remake the region," particularly the Grenada Revolution of 1983 and Michael Manley's democratic socialist experiment in Jamaica, to discuss what he calls "the coloniality of Caribbean citizenship." ${ }^{84}$ Drawing heavily on Hintzen's critique of Afro-Creole nationalism, Kamugisha contends that the inheritance of colonial state bureaucratic structures facilitated the continued legitimacy of colonial political and economic means of elite

80 Obika Gray, "Predation Politics and the Political Impasse in Jamaica" Small Axe 2003, 13: 73-74.

81 Ibid: 76.

82 Ibid: 78.

83 Ibid: 82.

84 Aaron Kamugisha, "The Coloniality of Citizenship in the Contemporary Anglophone Caribbean" Race \& Class 2007, 49(2): 22 
domination. ${ }^{85}$ Creole identity itself, Kamugisha argues, is a colonial discourse that privileges Euro-descended cultural forms by virtue of Europeans' place in the plantation complex. ${ }^{86}$ Creole nationalism, then, reflects European aspirations of the Caribbean middle class, and legitimates domination over the poor as more "Africanized" subjects. ${ }^{87}$

To varying degrees, these authors emphasize the social stratification of Caribbean postcolonies between an educated elite and an exploited working class, sharing an AfroCreole identity but unevenly sharing in the project of government. The political and economic institutions of the postcolony, and the colonial rationality that formed them, shaped the character of this stratification; in other words, the maintenance of colonial modes of power and knowledge shaped a particular understanding of the postcolonial public, economy, and their relationship to the state. Despite shifting the source of state legitimacy from metropolitan power to popular consent, a state apparatus governed by the same rules conceived government in mostly the same way, and the exploitative relationships of government and industry went on as before.

Canada is also a colonial creation; our imaginary of ourselves and our position in the world is influenced by ideologies of racism and empire passed down from our colonial experience. Canada has been characterized as a "white settler society," in reference to the European (specifically British in the case of Canada) colonial project to create a replica of the metropole overseas through mass European migration and the importation of metropolitan culture, goods and institutions. ${ }^{88}$ Political economists have

85 Ibid: 24.

86 Ibid: 26.

87 Ibid: 27.

88 Daiva Stasiulis and Radha Jappan, "The Fractious Politics of a Settler Society,", in Daiva Stasiulis and Nira Yuval-Davis (eds), Unsettling Settler Societies: Articulations of Gender, Race, Ethncity and Class 
used this formulation to help explain the paradox of Canada's economic "success story" despite its historically dependent position within the British Empire. ${ }^{89}$ Macdonald argues that Canada's perception as a "white settler colony," with its commensurate privileges, shaped its relations with "Britain's 'Other' colonial possessions" and facilitated a preferential position in the British imperial system. ${ }^{90}$

Daiva Stasiulis and Radha Jappan do not dispute this, but they also note the mythologizing nature of the "white settler colony" construct. While the "white settler colony" accurately describes Canada's national imaginary, it also obscures the role that indigenous peoples and non-European settlers play in shaping the country politically, socially and economically. ${ }^{91}$ Such a construct both facilitates and perpetuates the "systems of exclusion and exploitation" of racialized persons upon which Canada's prosperity and social achievements were built. ${ }^{92}$ Satzewich, Stasiulis and Nandita Sharma have each pointed to temporary foreign labour programs as one expression of these systems. $^{93}$

Stasiulis and Yuval-Davis argue that settler societies should be seen as existing on a continuum, broadly defined as "societies in which Europeans have settled, where their descendants have remained politically dominant over indigenous peoples, and where a heterogeneous society has developed in class, ethnic and racial terms," rather than as a fixed category. ${ }^{94}$ Although Jamaica is not typically characterized as a settler society, it is

(London: Sage, 1995): 97.

89 Macdonald: 115; Daiva Stasiulis and Nira Yuval-Davis in Stasiulis and Yuval Davis (eds): 4.

90 Macdonald: 116-117.

91 Stasiulis and Jappan: 98.

92 Stasiulis and Yuval-Davis: 4.

93 Nandita Sharma, Home Economics: Nationalism and the Making of Migrant Workers in Canada

(Toronto, U of T Press, 2006): 97; Stasiulis and Yuval-Davis: 18; Satzewich 1991: 35.

94 Stasiulis and Yuval-Davis: 3. 
not difficult to imagine how it would fit into such a continuum. Afro-Creole culture draws on, at least in part, European values, ideas and political institutions in creating and shaping a national identity. Anthropologist Diane Austin argues that the middle class uses these European signifiers as markers of their moral superiority over the working class, and as justification for their political dominance. ${ }^{95}$ Gray makes note of the "light skin" of political elites, suggesting that Jamaican social stratifications are marked by ethnic descent as well as culture. ${ }^{96}$ Austin disputes this, however, noting that "this elite has shifted its ideological emphasis from color to education, from birth to socialization, from "manners" to social competence, retaining all the while a qualitative component designed to maintain their privileged class position. ${ }^{197}$ Gray and Kamugisha both remark on the suppression of citizenship rights for the Jamaican working class. ${ }^{98}$ Denied full participation in their home nation, this class is recruited for migrant labour in Canada and is likewise excluded from their host nation.

Conceiving of both Canada and Jamaica as "settler societies" helps to explain the affinity between political elites that facilitates the exploitation of workers. Nevertheless, the ideology that shapes Canada's "white" imaginary does not include middle class Jamaican politicians and bureaucrats. Where Jamaican elites might see themselves as partners in the neocolonial project, this is not a perspective likely to be shared in Canadian policy circles, particularly not in the 1960s when the CSAWP was first implemented. One might expect friction from such a cognitive dissonance, but as we

95 Diane Austin, "Culture and Ideology in the English-Speaking Caribbean: The View From Jamaica" American Ethnologist 1983, 10(2): 236

96 Gray: 78.

97 Austin: 236.

98 Gray: 74; Kamugisha: 21. 
shall explore further in chapter three, the racist ideology that permeated the Canadian state when the CSAWP was first implemented was a surprisingly small obstacle to Canada-Caribbean relations.

\subsection{Shifting the Register: (Post)colonial Governmentality}

Postcolonial theory is helpful in historicizing the relationship between labour sending and receiving states, and examining the constructed nature of the political economies that shape them individually and bind them together. It illuminates the continuities of metropolitan rule in the postcolony through systems of knowledge and political projects that are based upon and uphold colonial cultural and racial hierarchies.

Neocolonial regimes are frequently described as being based upon an elite cultural or ideological affinity with the metropolitan power. Obika Gray, for example, makes particular reference to Edward Seaga's and Michael Manley's respective educations at Harvard and the London School of Economics. ${ }^{99}$ Jamaica's political leadership has no real cultural attachment to the underclass; they perform aspects of vernacular culture to create a sense of political legitimacy, but their real interests lie with the metropole. Kamugisha deconstructs the ideological choices in Afro-Creole nationalism to demonstrate the middle class' reluctance to challenge the structures of colonialism. ${ }^{100}$ While Afro-Creole nationalism claims a unitary national identity, it is an ideology created largely by and for the middle class that sustains elite domination over a voiceless majority through the persistence of colonial institutions. ${ }^{101}$ Nationalist ideology

99 Gray: 79.

100 Kamugisha: 24.

101 Ibid: 24. 
and appeals to shared identity are treated as instrumental fictions necessary to maintain domestic harmony but ultimately hollow.

Such an analysis begs several questions, most notably why mass anti-colonial demands of the 1940 s and 50 s, so skillfully channeled and co-opted by middle class political leaders, have not resurfaced to challenge neocolonial regimes. There is also ambiguity over what such a challenge might entail; beyond the Fanon appeal to 'forget Europe', confusion reigns over what a decolonized regime might look like. Gray and Kamugisha's contrasting assessment of Michael Manley is a perfect demonstration: Gray cites foreign-educated Manley as a player in the "predatory power" of the political elite. $^{102}$ Kamugisha, on the other hand, lists his democratic socialist government as one of the "radical attempts to remake the region." ${ }^{103}$ Such contradictions may themselves indicate why decolonization has proven so elusive; we appear to lack a clear understanding of what it means and how to achieve it.

In "Political Rationalities of the Jamaican Modern," David Scott demonstrates the limits of an ideology-centered analysis by comparing narratives about the birth of the modern Jamaican state. Examining both liberal and "radical" perspectives through the writings of Wendell Bell, Trevor Munroe and Ken Post, he sketches diverse stories of Jamaica's anti-colonial struggle and independence beginning with the "axiomatic" strikes of 1938. ${ }^{104}$ Bell emphasizes the "political maturation of middle-class leadership" and the adoption of British parliamentary democracy to manage the social upheavals of the nascent Jamaican public. Munroe outlines the birth and ultimate death of the Marxist

102 Gray: 78.

103 Kamugisha: 22.

104 David Scott, "Political Rationalities of the Jamaican Modern" Small Axe 2003, 7(2): 7-9 
anti-colonial movement in the People's National Party, and the bourgeois convergence of the political parties by the mid-1950s. Post largely eschews partisan politics to examine the formation of working-class consciousness, and the ultimate failure of its leadership in bringing about a workers' revolution. Within these contrasting narratives, with their particular emphases, heroes and villains, and teleologies, Scott discerns two fundamental assumptions:

That what is central to the history of Jamaica's political modernity is the trace of ideological antagonisms competing for control over the nation state project; and...the assumption, whether conceived from above or below, of a normative horizon of futures--whether nation or socialism--to be struggled over and achieved. ${ }^{105}$

Scott argues that this style of political analysis is inadequate to explain the unfulfilled promises of the postcolonial state, the so-called "end-point of the Bandung project." ${ }^{106}$ The crisis facing Jamaica and other postcolonies, he contends, is part of a global crisis of the modern nation-state, the very terrain upon which rival ideologies contest each other. ${ }^{107}$ The scope of the crisis calls for a new register of analysis, not structured around ideological oppositions but that concerns itself with understanding the forms and rationalities of government. ${ }^{108}$ To approach this agenda, he draws heavily on Michel Foucault's concept of governmentality.

Governmentality is a study of how authority conceives of, gathers and interprets information on, develops, evaluates and solves problems regarding the entity to be

105 lbid: 9.

106 Ibid: 2 .

107 Ibid: 6 .

108 Ibid: $10-11$. 
governed. ${ }^{109}$ These cognitive processes constitute a 'rationality' of government, a systematic approach to acting upon governed subjects in such a way that modifies their conduct. Distinct from ideologies which prescribe particular policies to identified probems, rationality (or mentality) of government is a set of ideas, commonly taken for granted, about what is to be governed, what are the proper practices of government, who we are when we are governed, and what are the goals of government and governed subjects. ${ }^{110}$ Key to this analysis is the recognition that there is no "true" rationality of government, that the types of information we collect and the forms of knowledge we produce to interpret those findings can form different systems of understanding and acting upon governed entities. ${ }^{111}$ Studies in governmentality seek to illuminate the contingency of rationalities by examining the sources, assembly and evolution of the regimes of practices that give them life. ${ }^{112}$

Mitchell Dean has identified a series of methodological "moves" that characterize governmentality studies. They begin with an identification of points of intervention in the lives of subjects around a particular problem of government. Priority is given to "how" questions, interrogating the practices of these interventions in terms of the intended and unintended effects, intended and unintended and the power relations at work in their operation. Regimes of practices are examined not as the expression of a particular principle or set of relations, but polymorphous complexes whose elements have their own histories that nevertheless when examined as a whole operate with their own logic. Analysis of these regimes follows four main points: the "forms of visibility"

109 Mitchell Dean, Governmentality (London: Sage Publications, 2010): 18.

110 Ibid: $25-27$.

111 Ibid: 19.

112 Ibid: 31 . 
necessary to their operation; the technical means, techniques, procedures, vocabularies, instruments that make up government's operation; the way that practises of government give rise to certain forms of knowledge, and the ways that government forms and reshapes the identities of its subjects. ${ }^{113}$

In asking how the Jamaican government negotiates its relationship with seasonal farm workers placed in Canada, I am posing a question about Jamaica's governmentality. How does the Jamaican government problematize its workforce? What forms of knowledge came to identify part of Jamaica's population as "surplus labour", and identified the temporary export of labour as a solution? What kinds of subjectivities are produced by the various practices that constitute the Overseas Employment Programme, and how do they impact state social and economic goals? An understanding of the program and the power relations that underpin it must come from an analysis of the rationality which governs its operation. My main methodological task is to examine the governing effects of the Overseas Employment Programme, and to connect the ways that it disciplines and shapes workers to fundamental assumptions (rationality) about what the Jamaican state does, and over whom and what it may legitimately claim authority.

As suggested by the postcolonial literature, the political rationality of the modern Jamaican state is closely connected to its colonial antecedent. As we shall explore in more depth in subsequent chapters, the normative assumptions of liberalism and the development project have historically shaped, and continue to shape, Jamaica's understanding of its population, particularly regarding poverty, labour and economic

113 Ibid: $37-43$. 
inequality. Mitchell Dean identifies two key features of liberal political rationalities which are crucial to this thesis: bio-politics and social government.

Bio-politics, as articulated by Foucault, entails the transformation of sovereign right from the "right to take life or let live" to the "power to 'make' live and 'let' die." 114 Bio-politics necessitates techniques of power that understand bodies as biological entities, and seek to control them by manipulating physiological processes. Birth rates, mortality rates, individual longevity all become political problems and fields of action for government. This understanding of bodies as living beings merges political questions with scientific problems. ${ }^{115}$ Mitchell Dean observes that bio-politics is a crucial feature of liberalism, in that they both operate through an observance and optimization of depoliticized scientific (and social scientific) processes that supposedly limit the scope of government intervention in the lives of subjects. ${ }^{116}$ As Dean notes, bio-politics cannot confine itself to the biological phenomena of life, it "must then also concern the social, cultural, environmental, economic and geographic conditions under which humans live, procreate, become ill, maintain health or become healthy, and die."117

Counterbalancing liberalism's minimalist governance through natural processes, Dean contends, is its tendency towards "social government." Although liberal government relies upon the creation of "rational and prudential subjects to exercise their liberty to pursue their interests", it must also contend with a diversity of subjects with divergent purposes and interests such as the poor, the "immoral", or the transgressive. ${ }^{118}$

114 Michel Foucault, Society Must Be Defended (New York: Picador, 2003): 241.

115 Ibid: 245.

116 Dean: 133.

117 Ibid: 119.

118 Ibid: 146. 
The problem of maintaining order amongst and between these subjects becomes the problem of society, a sphere of cultural, political and economic exchanges between subjects bound within the jurisdiction of the state. ${ }^{119}$ The relations between subjects cannot be regulated directly, as government is constrained by its observance of 'natural' laws; this dilemma, Dean argues, is resolved through philanthropy backed by expert knowledge, assistance granted to the poor or rehabilitation of criminals on the condition that they accept instruction on normative behaviours. ${ }^{120}$

Drawing on Scott, Anthony Bogues has outlined an historical development of the political rationality of the Jamaican state, beginning with the "command order of plantation slavery. ${ }^{121}$ The "problem" of government in this period concerned the orderly extraction of agricultural wealth in the form of sugar, achieved through the coerced labour of African slaves. Most of the population was understood to be human 'machines' without political or social rights, meaning that conduct was shaped largely through relations of brute force. Emancipation in 1834 changed the relationship between planters and labourers; although the goal of the colonial state remained to extract as much wealth from the colony for the benefit of absentee landowners, the changed legal status of workers required a new "art of government" to manage them. A new, more liberal project unfolded, to condition labourers in "Christian blacks" who embodied the values of values of European religion, family structure and wage labour. ${ }^{122}$

The postcolonial state was created and led by successful "Christian black" subjects, who articulated their demands for citizenship and national sovereignty around 
their embodiment of European values. The art of governing through European cultural values of work, family and property did not change, but these normative social patterns were appropriated as indigenous rather than imposed from metropolitan authorities:

A certain kind of citizen was to be created, one who would be Caribbean, who would be Creole, who would accept middle class leadership and values, who would wear respectability like a Sunday-best outfit, who would develop a nuclear family, labor in the factory or on the banana and sugar plantations, vote in elections, speak properly and softly, listen to good music, comport themselves with proper gestures, respect authority and uphold Christian values. ${ }^{123}$

The problematization of the "labour surplus", as we shall explore more fully in the next chapter, is related to this social project as much as it is to any economic project.

Jamaicans who were historically part of the plantation economy became subsistence farmers in the interior, posing difficulties for political and social authorities that sought to mold and control them as more perfectly "modern" subjects.

A liberal rationality of government also structures the relationship between Canada and Jamaica through the language and ideals of the development project. William Walters and Wendy Larner have discussed in detail developmentalism as an international rationality of government, as a successor to imperialism. The transition from an imperialist to a developmentalist logic governing international relations was based on reconceptualizing both the project of government and international space. Imperialism is an expansionary, universalizing project that sees territorial annexation and the subjugation of 'inferior' peoples as vital to the survival of the national organism. ${ }^{124}$ It

123 Ibid: 15.

124 William Walters and Wendy Lamer, "The Political Rationality of New Regionalism: Toward A Genealogy of the Region", Theory and Society 2002, 31(3): 397-398. 
is a zero-sum competition between nation-states that aspires to "fully universal assimilation into humanity", or the global reach of the 'victorious' state. ${ }^{125}$

Developmentalism also poses an international competition between states, but it aspires to a maximization of global welfare while respecting the sovereignty and territorial integrity of nation-states. The world system is imagined as a "jigsaw" of nation-states as discrete political and economic entities, whose primary legitimate interaction is through trade. Metropolitan states no longer wield authority over a 'backwards' periphery by virtue of civilizational superiority, "but in the name of more abstract natural and social-scientific norms" that posit their infrastructure, economic models and social achievements as the model to which poorer, weaker states ought to aspire and stronger states have a moral obligation to help them attain. ${ }^{126}$ The point is that imperialism and developmentalism share certain congruities, but as the rules and objects of international politics change, the logic that shapes colonial projects changes with them.

\subsection{Conclusion}

Satzewich and André provide us with a useful explanation of why Caribbean workers end up on Canadian farms, grounded in the dialectical contradictions of capital accumulation on a world scale. But their approaches do not explain the power relations within the program, particularly the apparent affinity between the Caribbean and Canadian governments in facilitating the exploitation of Caribbean workers. To understand this, we must examine Canada and the Caribbean states as creations of an imperial system, whose use of temporary foreign work programs are shaped by colonial ideas of citizenship and economy. CSAWP generates remittance income for Jamaicans 
and the Jamaican state, but it also assists the Afro-Creole project of creating "respectable black" subjects who function within European ideas of wage labour, family and society. It is a tool for preserving social stability and fashioning the postcolony more perfectly in the image of Anglo-Saxon ideals. The next chapter will examine more closely the historical formation of the "respectable black" subject. 


\section{Chapter: "I Going Away, I Going Home": A Brief History of}

\section{Jamaican Labour Migration, 1838-1966}

\subsection{Introduction}

Caribbean history post-European contact is foremost a history of migration. From the moment of European arrival, successive waves of free and coerced migrants drawn by the plantation economy shaped and reshaped the demographic, institutional and political economic profile of the region. European, African, South and East Asian migrants have each left distinct cultural imprints. European settlement was often transitory from the 16th century onward, but the abolition of slavery in various territories led to sustained regional migration and outmigration of freed slaves and their descendants. ${ }^{\text {ii }}$ Monica Gordon contends that the migratory experience, captured in the title of Wilfred Cartey's review of Caribbean literature Whispers From the Caribbean: I Going Away, I Going Home, is crucial to understanding both the dependency relationship of the Caribbean to Europe and the political and social ideals of the anti-colonial movement. ${ }^{127}$ The cycle of emigration and return, she argues, serves as a "bridge" between home and host countries creating vital export markets for Caribbean goods, channels for remittance and the source of "social transformation" at home through their experience abroad. One of my central arguments is that the migration experience is also crucial to the formation of certain subjectivities drawn from Jamaica's colonial experience.

127 Monica Gordon, "The Role of Emigration in the Caribbean Development Process" in Perry Mars and Alma H. Young (eds), Caribbean Labor and Politics: Legacies of Cheddi Jagan and Michael Manley (Detroit: Wayne State University Press, 2004): : 227-228. 
A number of scholars have made note of Jamaica's long history of labour migration. Irving André, Cindy Hahamovitch and William Green describe large-scale movements of Jamaicans throughout the Caribbean and the Americas, beginning in the 1880s with Ferdinand de Lesseps' attempt to build the Panama Canal. ${ }^{128}$ Elizabeth Thomas-Hope claims that emigration began shortly after the abolition of slavery, noting that Jamaicans migrated to Panama in the 1850 s to build the isthmus railroad, and that some participated in the California gold rush of the $1840 \mathrm{~s} .{ }^{129}$ Likewise, the scholarship describes these movements as driven by a persistent "labour surplus." ${ }^{130}$ But this narrative poses an odd paradox: the intensification of outmigration in the $1880 \mathrm{~s}$ accompanied the intensified immigration of indentured labourers from India. ${ }^{131}$ Jamaica simultaneously experienced a surplus of labourers and a shortage of labour power.

The purpose of this chapter is to attempt a resolution of this paradox by examining the idea of a labour surplus in a more critical light. My argument is that perceptions of Jamaica's 'labour surplus' are the product of a particular imaginary of the Jamaican political economy rooted in the British colonial function of the island as a source of sugar. The Jamaican government's rationale for participating in temporary foreign work programs such as the United States' H2 program and the CSAWP is rooted in the labour problems of the plantation economy following the abolition of slavery. The difficulty of inducing freed slaves to continue working the plantations, coupled with the

128 William A Green, "The West Indies and Indentured Labour Migration - The Jamaican Experience" in Kay Saunders (ed), Indentured Labour in the British Empire 1834-1920, (Beckenham, Kent: Croom Helm Ltd, 1984): 32; André: 253; Hahamovitch: 52.

129 Elizabeth M. Thomas-Hope, "The Establishment of a Migration Tradition: British West Indian Movements to the Hispanic Caribbean in the Century After Emancipation" in Colin A. Clarke (ed) Caribbean Social Relations (Center for Latin-American Studies, University of Liverpool, 1978): 66. 130 André: 245; Thomas-Hope: 66.

131 Green: 32. 
violent uprising in Morant Bay in 1865, constructed discourses about Jamaica's protopeasantry that proved important to the development of labour migration as a means of managing them. These conditions created the perception of a "surplus population" on the island, connected that surplus to the poor morals and work ethic of impoverished subsistence farmers in rural hinterlands, and made colonial officials and the planter elite keenly aware of the potential for social unrest as a result. Colonial and post-colonial governments encouraged poor Jamaicans to seek work abroad as a strategy to manage social unrest, identified with the problem of 'irresponsible' poor people unwilling to work. This encouragement became institutionalized in overseas employment programs as a result of closing international borders and the growing sophistication of state interventions to discipline working bodies.

In this chapter I outline a cursory history of Jamaican labour migration from the end of apprenticeship in 1838 to the development of the CSAWP pilot programme in 1966 to recruit Jamaicans for work on Canadian farms. The analysis is primarily a critical synthesis of secondary literature that requires a certain re-periodization; a number of scholars have touched on migration from abolition to the interwar period or on the post-war development of temporary migration programmes; these phases have not received attention as a single narrative. My emphasis is on demonstrating the continuities between the early migration ventures and later programmes, and the colonial understandings of Jamaican labour and the Jamaican economy that underpin them.

\subsection{Emancipation and the Emergence of a Jamaican Peasantry}

The Slavery Abolition Act of 1833 formally ended slavery throughout most of the British Empire. Effective August 1, 1838, after a period of 'apprenticeship' meant to 
"prepare the slaves for wage labour" while indentured to their former masters, the Afrodescended peoples of the Caribbean were to receive the full legal and political rights of free British subjects. ${ }^{132}$ In Jamaica this meant the emancipation of roughly 311000 men, women and children, mostly employed on sugar plantations. ${ }^{133}$ The end of a 300 year-old system of forced labour was a monumental social and economic experiment.

Abolitionists saw British emancipation as the first step in a global campaign to eradicate slavery and the African slave trade. ${ }^{134}$ The large-scale conversion of sugar plantations from forced to free labour was expected to prove the "axiom" that "slave labour...is dearer than free," by making labour more productive. In this sense, the British West Indies were expected to serve both as a moral example to other European powers and protect the sugar industry from the anticipated reduction of protective sugar tariffs. ${ }^{135}$ It was by no means certain to all that former slaves and former planters would live peaceably side-by-side, that the sugar plantations would continue to function, or that colonial assemblies would respect the freedoms of former slaves. As Lord George Harris observed, "a race has been freed, but a society has not been formed." 136

Anthony Bogues notes that emancipation represented a shift in the colonial "art of government", from the command order of violent discipline that characterized slavery to a more liberal art focused on creating industrious, Christian, 'rational' subjects of the

132 Thomas C. Holt, "The Essence of the Contract: The Articulation of Race, Gender and Political Economy in British Emancipation Policy, 1838-1866" in Frederick Cooper, Thomas C. Holt and Rebecca J. Scott (eds), Beyond Slavery: Explorations of Race, Labor and Citizenship in Postemancipation Societies (Chapel Hill: University of North Carolina Press, 2000): 44 133 Sidney Mintz, Caribbean Transformations (Chicago: Aldine, 1974): 158.

134 Green: 7.

135 Ibid: $10-11$.

136 Quoted in Holt: 33. 
freedpeople. ${ }^{137}$ Both the timing and the nature of this shift coincide with the changes Foucault documented in European penal systems, where punishment was no longer enacted on the body but "on the heart, the thoughts, the will, the inclinations." ${ }^{138}$ Thomas C. Holt connects the emancipation project to the hegemonic ascendance of liberalism in Britain. ${ }^{139}$ Freeing the slaves represented both an affirmation of and a project to instill "bourgeois values" deemed crucial to the functioning of a liberal society. The success of this project would be measured, by abolitionists, planters and British colonial officials alike, primarily in the peaceful and prosperous functioning of the sugar plantations under the new order. ${ }^{140}$

The post-Emancipation social order unfolded differently in Britain's various Caribbean territories, with consequences for the economic order. Unlike the small, flat islands of the Eastern Caribbean, Jamaica, Trinidad and Guiana were all relatively large, with an abundance of unsettled land not suitable for sugarcane cultivation. ${ }^{141}$ Of the large islands, Jamaica had a much longer history of British settlement and plantation agriculture. The soil was relatively less fertile from long use. Sugar production was already in decline prior to emancipation. ${ }^{142}$ Moreover, Jamaica was unique among the Anglo-Caribbean colonies in that slaves were often allowed, in their spare time, to cultivate their own food on estate lands not needed or wanted for sugar cultivation. This subsistence farming developed into customary Sunday markets throughout the island,

137 Bogues: 13-14.

138 Michel Foucault, Discipline and Punish: The Birth of the Prison (New York: Vintage, 1995 [1977]):

16.

139 Holt: 39.

140 Green: 8 .

141 Ibid: 2.

142 Herman Merivale, Lectures on Colonization and Colonies (New York: Augustus M. Kelly, 1967

[1861]): 315 . 
where slaves sold their own produce, keeping for themselves the money or goods they received. ${ }^{143}$ The availability of unused land and the considerable skill and experience Jamaican freedpeople already possessed in growing and marketing encouraged them to leave the plantations once apprenticeship ended, settling the interior as an emergent peasantry. Others sought to make a life abroad in Guatemala, Honduras or even as part of the California gold rush, although these movements appear to have been small-scale. ${ }^{144}$ There were three avenues for freedpeople to acquire farmland in Jamaica. Some were able to purchase parts of abandoned plantations, or surplus land from otherwise viable estates, although the British colonial office sought to keep land prices out of the reach of most freedpeople. ${ }^{145}$ Others simply squatted on Crown or abandoned estate land. But the majority settled in "free villages", communities founded by Baptist or Methodist missionaries for the settlement of freedpeople as yeoman farmers. As many as 19000 families settled in such communities; Mintz suggests that "this figure may represent an aggregate of as many as 100,000 persons." ${ }^{146}$ The free villages were communities of roughly a hundred families, organized around a church congregation. Residential and farm land was purchased and surveyed by the church, then resold in parcels to freedpeople, who paid in installments and may have been partially subsidized by philanthropic contributions from London congregations. ${ }^{147}$ Families grew a variety of crops for their own consumption, as well as for domestic trade and export. The villages

143 Mintz: 182-183.

144 Thomas-Hope: 66.

145 Holt: 48.

146 Mintz: $159-160$.

147 Ibid. Missionary reports quoted by Mintz allude to 'outside contributions' that help pay for land parcels, but do not specify their source or nature. 
also included a school, run by the founding church and maintained by the contributions from the villagers. ${ }^{148}$

It is clear that ecclesiastical authorities intended these communities to provide residents with moral as well as material fulfillment. Churches were staunch advocates for Emancipation, and fought planters and imperial authorities to protect the rights of freedpeople. ${ }^{149}$ Mintz argues this was because the planters were an obstacle to their efforts of Christianizing the slaves. ${ }^{150}$ Green suggests support for abolition came from "the fundamental principles of the Christian religion," increasingly entwined with an ideology of free labour. ${ }^{151}$ The free villages minimized planter's power over the exslaves, and created, it was hoped, a demonstration of the redemptive value of Christianity and free labour on freedpeople's social welfare. Missionaries resided in the villages; others periodically visited from Britain to inspect village sites, reporting back to church authorities on both on the economic progress and piety of the villagers. ${ }^{152}$ Abolitionists used evidence of how "liberated people had hastened to embrace Christian worship, marriage and education" as part of the proof of the success of the emancipation experiment. ${ }^{153}$

The free villages were not, however, intended to dissuade freedpeople from working on estates. While they removed freedpeople from living on the estates and provided them their own land for subsistence, it was hoped that yeoman homesteads, Christianization and nuclear families would induce freedpeople to seek a life beyond

148 Ibid: $161-167$.

149 Green: 8.

150 Mintz: 158 .

151 Green: 8.

152 Ibid.

153 Ibid: 9 . 
subsistence, seeking work and accumulating capital to support, and supported by, a domestic family structure. A speech by Richard Chamberlaine, an Afro-Jamaican colonial magistrate, at a dinner of freedpeople celebrating the end of apprenticeship illustrates the abolitionist's vision:

Your wives and daughters will require their fine clothes for their chapels, churches and holidays. You will visit your friends with your coat and your shoes, and you will require your dinners prepared for you with some respect to comfort and cleanliness; your soup will be seasoned with beef and pork; and in order to obtain these, the comforts and necessaries of civilized life, you will have to labour industriously--for the more work you do, the more money you must obtain, and the better will you be enabled to increase and extend your comforts. ${ }^{154}$

Missionaries and abolitionists likewise exhorted freedpeople to work willingly on the plantations, to prove the value of emancipation: "You strengthen the fetters of the slave in other lands, by giving colour to the charge, that if not compelled by force to labour as he is, he would be as idle as you are." 155

Nevertheless, the majority of Jamaican freedpeople chose to devote most of their time and energy to their own farmlands, finding work on the plantations sporadically when they needed extra income. ${ }^{156}$ Jamaica's sugar production continued to decline, prompting a crisis in the funding and maintenance of public infrastructure and threats that planters (and their capital) would desert the colony. ${ }^{157}$ But the perceived problem in Jamaica, up to the 1860 s, was a labour shortage, not a surplus. The British colonial office implemented a series of immigration schemes to boost the Jamaican population, thereby discouraging freedpeople from settling in the interior and creating more pliant labour

154 Richard Chambelaine, quoted in Holt: 45-46.

155 Green: 9.

156 Thomas-Hope: 70.

157 Green: 10. 
sources for the estates. In 1840, 2400 hundred Europeans arrived to take up smallhold farms in the mountains, but they were ill-suited to farming; many died, and most others left for the United States. ${ }^{158}$ By 1841 , planters were recruiting labourers from Sierra Leone, but after an initial burst of enthusiasm from labourers, numbers declined as a result of rumours that migrants were being pressed into slavery. ${ }^{159}$ Indentured labourers began arriving from India in 1844 , but the combined catastrophes of drought, plummeting sugar prices from the impact of the Sugar Duties Act and international economic depression withered Jamaica's sugar industry further. Jamaican planters found Indian labour expensive and unsuited for sugar cultivation, and stopped immigration by $1846 .{ }^{160}$

Green asserts that in a series of Oxford lectures between 1839 and 1841 , prominent contemporary political economist Herman Merivale argued for "'copious immigration' to the larger West India colonies," Jamaica included, but this is something of an oversimplification. ${ }^{16 I}$ Merivale classified Britain's Caribbean colonies into three types, based on their patterns of settlement and land tenure. ${ }^{162}$ The first category characterized the smaller Antilles: small, flat islands that were thickly populated and whose land was almostly employed in sugar cultivation. Guiana and Trinidad belonged to another category, thinly settled colonies that still had large amounts of land suitable for sugar plantations, but lacked the population and the capital to exploit it as yet. Jamaica was in a category by itself: as discussed above, the island had plenty of unsettled land,

158 Ibid: 5.

159 Ibid: 12 .

160 Ibid: $19-21$.

161 Ibid: 14 .

162 Merivale: $313-318$. 
but it was poorly suited for sugar cultivation. The balance between labour and land use was key to his prescription:

The immigration of free labourers could produce no benefit in the smaller Antilles, which are over-peopled already; its advantage would be very doubtful in Jamaica, where the people are sufficient for the work to be done, and the present disinclination to labour, and high rate of wages, may perhaps arise from temporary causes only; for Demerara and Trinidad it is the one great requisite, the sina quâ non of their future prosperity. ${ }^{163}$

Merivale's specific prescriptions for Jamaica are unclear, and perhaps reflective of a general angst over how to rescue the declining colony. The plantations, he argued, were a precarious affair in Jamaica which survived only as a result of protectionist sugar duties which were soon to be abolished. Their economic difficulties had "an origin long anterior to emancipation," and only "some new development of energy which freedom may peradventure exhibit" was bound to turn around the island's sagging economic fortunes. ${ }^{164}$ But even in an 1860 appendix to his lectures, Merivale did not suggest the island suffered from a surplus of labour. ${ }^{165}$ In any event, the myriad attempts to induce immigration suggest that neither colonial authorities nor Jamaican planters perceived that the island had an excess of workers.

Perhaps Merivale's most striking observation linked the fortunes of the sugar industry, particularly in Jamaica, to the success of the emancipation experiment and the redemption of the freedpeople. Invoking the specter of Haiti, he warned that the collapse of the estates and the wage labour it offered would reduce the "half-civilized freedmen"

163 Ibid: 318 .

164 Ibid: 316.

165 Ibid: 342 (appendix, 1860). 
to "the indolence and apathy so natural to their climate and condition; content themselves with an easily acquired subsistence, and relapse by degrees into the savage state." ${ }^{166}$

\subsection{The Morant Bay Rebellion}

Jamaica suffered a series of shocks in the 1840s and 50s. Drought struck the island numerous times, causing the failure of both subsistence farms and sugar estates. The Sugar Duties Act, introduced in 1846, removed protective tariffs on sugar, giving slave states such as Cuba and Brazil better access to British markets. By 1847, the price of sugar had dropped below the cost of production in Jamaica. An international economic depression exacerbated the commodity price crisis and precipitated the failure of the Planters Bank of Jamaica in 1848. ${ }^{167}$ Smallpox, influenza and cholera swept through the island in the early 1850s. ${ }^{168}$ The environmental stresses pushed yeoman farmers to seek work on the plantations, that were themselves financially and environmentally precarious. Work was scarce and wages plummeted. ${ }^{169}$

In the 1860 appendix to his lecture on emancipation, Merivale described a confused, paradoxical situation in Jamaica and his own loss to adequately explain what was happening or why:

Judged by the test of statistics, its decline is evident; and the observations of eye-witnesses go far to confirm, in some respects, the result thus obtained. The higher classes have suffered greatly; and yet the middle class seems to be very numerous and advancing in prosperity. There are in Jamaica, we are told, 70,000 coloured people, all, or nearly all, of the commercial order. There are 300,000 of the negro labouring class. The first seem to possess a fair share of the comforts, and some of the luxuries of life. Whether the latter are improving

166 Ibid: 320.

167 Green: 20; Merivale: 338 .

168 Green: 26.

169 Thomas-Hope: 70. 
or declining in condition is much disputed; but there can be no doubt they have a superfluity beyond the necessary minimum of wages, and that some of them spend considerable sums for purposes of enjoyment. ${ }^{170}$

Despite the worsening economic situation into the 1850s, Thomas-Hope asserts that outmigration declined after the completion of the Panama isthmus railroad. ${ }^{171}$ In 1858 , the colonial legislature renewed the importation of indentured labour from India, albeit with stricter provisions to ensure the workers left upon the expiry of their contracts. ${ }^{172}$ This wave of immigration peaked in 1862 , before another collapse in sugar prices decimated the estates yet again. ${ }^{173}$ Meanwhile, missionaries appealed to British churches for funds to maintain the free villages in the face of growing poverty and declining local funds, and to pressure the British Parliament to intervene "on behalf of the nation." 174 How the imperial government should intervene was far from clear. Two sharply contrasting narratives emerged to explain Jamaica's troubles. Planters and their lobbyists in London, the West India Interest, blamed freedpeople for refusing to work on the estates, shunning the benefits of religion and nuclear families, preferring to eke out a subsistence in the mountains while the plantations went to ruin. ${ }^{175}$ A diverse but less politically powerful group of missionaries, merchants, wealthy Afro-Jamaicans and some colonial officials blamed the mismanagement and hostility of the planters, who refused to update their agricultural or labour techniques and pinned their fortunes on hopes of a retrenchment of freedpeople's legal, political and social rights. ${ }^{176}$ As time went on,

170 Merivale: 342 .

171 Ibid.

172 Green: 27.

173 Ibid: 28.

174 Horace O. Russell "The Reactions of the Baptist Missionary Society and the Jamaican Baptist Union to the Morant Bay Revellion of 1865" Journal of Church and State 1993, 35(3): 598; Mintz: 167. 175 Holt: 54-55.

176 Green: 8; Merivale: 341 
however, the Colonial Office appeared to side with the planters. The stereotype of the 'Quashee', the lazy, immoral, and sexually promiscuous Afro-Jamaican with no regard for the future, was a prominent feature of colonial reports to London. ${ }^{177}$

Despite decades of declining production, the association between the health of the sugar industry and the overall economic strength of the island appears to have strengthened. In January 1865, Edward Underhill of the Baptist Missionary Society wrote to British Colonial Secretary Edward Cardwell, outlining the "continually increasing distress of the coloured population." ${ }^{178}$ Underhill's appeal for the colony included a plan for economic reform, encouraging the cultivation of non-sugar export staples (coffee, cotton, spices and tobacco) on freehold farms by "equalizing duties on the produce of the people and that of the planting interests" and the formation of cooperative shipping associations to market the produce. ${ }^{179}$ The Underhill letter does make reference to a labour surplus in Jamaica, although it is clear he does not consider it a structural issue but a temporary situation brought on by the crisis in the sugar industry and the legal and economic difficulties of diversifying Jamaican exports. ${ }^{180}$

Cardwell forwarded the letter to Governor Eyre of Jamaica, who held a series of public meetings to discuss its contents. These meetings became a forum for criticism of Eyre's policies. ${ }^{18 I}$ Nevertheless, he responded to Cardwell that there was no crisis in Jamaica, and that "many of the Peasantry are under considerable misapprehension as to the relative advantages they enjoy, or the disadvantages they labour under, in Jamaica, in

177 Holt: 55 .

178 Edward Underhill, "A Letter Addressed to the Rt. Honorable E. Cardwell With Illustrative Documents on the Condition of Jamaica and an Explanatory Statement" (London: Arthur Miall, 1866): 11.

179 Ibid: $14-15$.

180 Ibid: 11-12.

181 Russell: 597. 
comparison with similar Classes in other Countries." ${ }^{182}$ A year prior, Eyre gave similar advice to a black peasant farmers petitioning for land reform. The solution to their economic distress, he admonished, was to "improve in civilization," by adhering to Victorian standards of education, dress, work ethic and sexual restraint. ${ }^{183}$

1865 saw the violent culmination of environmental, economic and social stresses. Once again, the island was in the midst of an extended drought. ${ }^{184}$ Sugar prices were depressed and the civil war in the United States drove up import prices, placing the sugar plantations in the vice of a cost-price squeeze. ${ }^{185}$ Peasant farmers from St. Thomas had again petitioned the colonial assembly for land reform and tax relief, but were dismissed by Governor Eyre without so much as an opportunity to air their grievances. ${ }^{186}$ In October of that year, protests by farmers from St. Thomas shut down a session of the Petty Sessions Court in Morant Bay. Tensions escalated over several days, until a mob led by Baptist deacon Paul Bogle killed a number of colonial and church officials, including the custos, Baron von Ketelholdt. ${ }^{187}$

Eyre had the rebellion put down with considerably more violence than the rebels had shown. Along with "widespread butchery" by the colonial militia to restore order in St. Thomas, Bogle and his family were hung. William Gordon, a Jamaican Assemblyman who had nothing to do with the revolt but had been a prominent critic of Eyre, was also tried "before a kangaroo court" and executed. The British Parliament abolished Jamaica's colonial legislature shortly thereafter, instituting direct Crown rule

182 Underhill: 4; see also Russell: 598-599.

183 Holt: 55.

184 Thomas-Holt: 70.

185 Green: 28.

186 Russell: 598.

187 Ibid: $599-601$. 
over the colony. Impoverished peasant farmers were no longer merely a moral problem or an economic obstacle to the plantation economy. They had proven themselves, in the minds of planters and metropolitan colonial officials, to be a potential threat to the social and political order.

Both emigration and immigration intensified following Morant Bay. Jamaicans began leaving for Costa Rican banana plantations in 1872. By 1882, a thousand workers a month were leaving for Panama to work on Ferdinand de Lessep's ill-fated attempt to build a canal, and as many again sought jobs when a US company resumed construction in 1904. Tens of thousands built railroads and worked on banana plantations in Costa Rica between the 1880s and the 1920s. Almost 50000 Jamaicans went to work on Cuban sugar plantations by the end of World War One, and 30000 entered the United States over the same period. ${ }^{188}$ Many of these trips were circular; Jamaicans would complete several cycles of migration and return, and few would return to estate work or subsistence farming on a permanent basis. ${ }^{189}$

Over the same period, the Crown colony government reintroduced immigration from East Asia; almost 30000 indentured workers arrived between 1867 and $1914 .{ }^{190}$ The number of workers brought in dwarfs the number that left, but the arithmetic does not diminish the paradox of a simultaneous labour shortage and labour surplus. Green notes the irony that Jamaicans "left an island suffering labour shortages in the sugar industry in order to secure other employment." ${ }^{191}$ Indeed, an 1882 editorial in The Jamaica Gleaner lamented that planters were paying a premium to import indentured 
labour while Jamaicans are recruited away to Panama and San Domingo. ${ }^{192}$ The further irony is that a great number of those migrants took up work in plantation agriculture, mostly sugar or bananas. Thomas-Hope observes that "in many cases cane cutters will work in virtually any country other than their own," but the puzzle presented merits closer investigation. ${ }^{193}$

Thomas-Hope contends that these migratory movements were "laissez-faire," occurring with neither the encouragement nor the hindrance of British officials. ${ }^{194}$ But while they may not have interfered directly in labour recruitment, one of the first acts of the Crown Colony government was to pass a series of laws that enabled the confiscation of lands for the non-payment of taxes. ${ }^{195}$ The effect was the widespread dispossession of freehold farmers, impoverished and indebted after years of economic decline. Without the farming subsistence to sustain themselves and their families, or threatened with its loss, Jamaica's proto-peasantry had to seek paid employment, especially abroad.

\subsection{The United States H2 Program}

The age of large intra-Caribbean migrations came to an end over the 1920 s and $30 \mathrm{~s}$ as a result of tightening borders in the destination countries. Panama shut its doors to further West Indian migrants after the completion of the canal in 1914. In 1924, the United States severely restricted Caribbean migration to 1000 immigrants per colony; a

192 Editorial, The Daily Gleaner, September 14, 1882.

193 Thomas-Hope: 70.

194 Thomas-Hope: 73.

195 Frederick Douglass Opie, Black Labour Migration in Caribbean Guatemala 1882-1923 (Gainesville, LF: University Press of Florida, 2009): 17. 
number of Latin American countries followed by banning Caribbean migration completely. Deportations rose as the Great Depression savaged the global economy. ${ }^{196}$

Hard economic times on the island, coupled with the loss of labour outlets meant the return of the tensions that preceded the Morant Bay uprising. The character of the subalterns had changed dramatically since 1865 ; the peasant farmers had been replaced by an organized proletariat. Jamaicans had earned money and become proletarianized abroad; but they had also been exposed to nationalist, trade union and revolutionary socialist ideas. ${ }^{197}$ They brought this experience to bear in struggles for social and political rights.

David Scott describes the 1938 dock workers' strike as the "axiomatic beginning" of Jamaica's political modernity, "dense with the almost cinematic signifiers that map the terrain of our anticolonial project and the horizon of our sovereignty." 198 What began as a pay dispute by employees of the West Indies Sugar Company in Westmoreland quickly spiraled into a national outpouring of anger over economic conditions, political disenfranchisement and social inequality. Strikes and riots brought Kingston to a standstill, prompting the British imperial government to introduce political and economic reforms, including universal suffrage and the legalization of trade unions. ${ }^{199}$ Both of Jamaica's major political parties, the Jamaica Labour Party (JLP) and the People's National Party (PNP), their iconic leaders (Alexander Bustamente and Norman Manley,

196 Hahamovitch: 52-53; Thomas-Hope: 74-75.

197 Hahamovitch: 53

198 Scott 2003: 7.

199 Nicole Bourbonnais, "'Dangerously Large': The 1938 Labor Rebellion and the Debate Over Birth Control in Jamaica" New West Indian Guide 2009, 83(1\&2): 47. 
respectively) as well as the Jamaican trade union movement emerged from the heated labour struggles of 1938 .

Alongside the pitched social unrest, a public debate arose over birth control. Nicole Bourbonnais documents 262 birth-control related articles published in The Daily Gleaner between June 1938 and March 1939, part of an emerging national movement to provide birth control measures for the poor. Bourbonnais argues that the repatriation of 30000 migrant labourers coupled with the depressed economic circumstances gave rise, despite declining fertility rates, to concerns about island overpopulation and its relationship to social welfare. ${ }^{200}$ Jamaica's birth control movement was embraced by a range of middle-class reformers and anti-colonial nationalists, including Norman Manley. ${ }^{201}$ Critics, most prominently Jamaica's Catholic clergy, acknowledged the population problem, but argued the solution lay in religious education, living wages and improved housing. The terms of the debate resurrected "Quashee" stereotypes about the loose sexual morals and weak family commitments of the poor: both sides of the argument explicitly linked population stresses to "sexual over-indulgence" resulting in the "highest illegitimacy birth rate in the world [emphasis mine]." ${ }^{202}$

The intertwined problems of the poor's promiscuity and prolific illegitimacy were discursively linked to social disorder and economic stagnation. In a summer when riots and strikes brought Kingston to a halt, Daily Gleaner editor Herbert George de Lisser argued that illegitimate children "are apt in time of trouble to behave with the same

200 Bourbonnais: $40,44$.

201 Ibid: 51.

202 Ibid: 40. 
irresponsibility as brought them into being. "203 Edward McCullough, a Jamaican physician and public advocate of the Birth Control Movement, made his case in explicitly Malthusian terms, if the population continued to grow: "instead of any improved standard of living for the people...standards will be lower than they are now."204 Manley himself argued that Jamaica, with a population of 1.25 million living on two million acres, was too overcrowded to provide the two and a half acres economists estimated each person required to live comfortably. ${ }^{205}$

The birth control debate disappeared from the public eye in the spring of 1939 , as order was restored in Jamaica. ${ }^{206}$ Its timing signifies how struggles over economic justice, political suffrage and labour rights intersected with concerns about the morals of the poor. It also demonstrates how biopolitics imposed itself on moral and political questions. Neither advocates nor critics of birth control questioned the premise that Jamaica was overpopulated, stemming from "over-breeding" by poor Jamaicans, despite the declining birth rate. The fault lines of the argument were over how to manage working class fertility, not whether it was a problem. ${ }^{207}$ As Bourbonnais argues, even the architects of Jamaica's anti-colonial movement, arguing for the democratic inclusion of working-class needs, perceived working-class behaviours as something to be controlled. $^{208}$

Given this, Cindy Hahamovitch's account of Jamaica's entry into the United States H2 farm work programme is somewhat puzzling. In 1943, after years of informal talks 
between Florida sugar growers and the governor of the Bahamas, the United States government and the British Colonial Office agreed to allow the import of 5000 Bahamians to relieve wartime shortages of agricultural labour. ${ }^{209}$ This was negotiated and operated separately from the Bracero programme that recruited Mexican labour for California farmers, although the programs shared a number of institutional features. The Bahamian program, operated under the auspices of the US War Food Administration, was quickly expanded to include Jamaicans, on the caveat that Jamaican workers would not be employed on farms south of the Mason-Dixon line. ${ }^{210}$

Unlike previous migratory movements, the US farm work programme was tightly managed by the United States and Jamaican governments. Many of its institutional features would later become part of the CSAWP. Workers were recruited directly by members of the Jamaican Legislative Council, screened by US government officials, brought to the United States by US Navy transport, and housed in camps built and maintained by the Farm Security Administration. They were contracted to specific farms on fixed terms, and required official permission to change jobs. Liaison officers, hired from Jamaica but paid by the US government, supervised work conditions and mediated conflicts between workers and employers. ${ }^{211}$ A quarter of farm workers' pay was deducted and held by the Jamaican government as an insurance that workers would return to the colony when their contract was up. ${ }^{212}$

In spite of the pressing social crisis and rampant unemployment, Jamaica's Legislative Council capped Jamaican participation at 10000 despite American 
willingness to accept up to 100000 workers. Jobs went not to impoverished farmers, but primarily to men, or the sons of men, with whom Council members wanted to curry political favour. As a result, the first cohort of workers was a worldly, educated and upwardly-mobile group. ${ }^{213}$ Many took correspondence courses while they worked on US farms. Leaford Williams, one of the original participants, used his earnings from the program to attend the American University in Washington, and went on to a distinguished career as a lecturer and US diplomat. ${ }^{214}$

On farms in the northern states, Hahamovitch argues that the sophisticated first cohort, with liaison officer assistance, was able to successfully assert their rights. ${ }^{215}$ But before the first season was over, the situation changed dramatically. Pressure from the United States soon removed restrictions on Jamaicans working in the south. ${ }^{216}$ In the Jim Crow south, where entrenched racism and a consolidated sugar industry prevailed, abuse was harder to avoid. Liaisons found it more difficult to find alternate work for workers dissatisfied with conditions on the farm. The only options were frequently repatriation to Jamaica or acceptance of gruelling conditions. The Jamaican government largely ignored reports of worsening work conditions in the program and focused on "expanding the program," confusing given they had initially capped participation. ${ }^{217}$ Public enthusiasm for the program was strong; small riots broke out as people clamoured to get farm work tickets. People who volunteered specifically to work in Florida sugarcane fields found it much easier to obtain a place in the program, further

213 Ibid: $55-56$.

214 "Farm Worker Turns Diplomat", Jamaica Gleaner, March 11, 2000.

215 Hahamovitch: 65.

216 Ibid: 70

217 Ibid: $77-78$. 
undermining the position of workers who tried to stand up to abusive practices. ${ }^{218}$ Farmers began screening out people with union affiliation or extensive overseas travel, ensuring more pliant workers arrived to the fields. ${ }^{219}$

The US farm programme was originally intended as a temporary measure to relieve perceived labour shortages brought on by American entry into World War Two. But lobbying by major growers of sugar, cotton, fruits and vegetables in 1945 was successful in extending the program, and including other Anglo-Caribbean colonies in the labour pool. ${ }^{220}$ Hahamovitch contends that US agri-business valued the migrant labour program because it gave them a tool with which to undermine the bargaining power of domestic farm workers. ${ }^{221}$ The major postwar change to the program was the end of US government involvement in recruiting foreign labour. Farmers now took responsibility for the hiring (and firing) for the transport and housing of workers and for paying liaison officer salaries, which is to say that these costs were passed on to workers. Farmers also negotiated the right to "pre-designate" individual workers they had been previously impressed with, to return to their farms. Hahamovitch notes that Jamaicans protested these changes, but the ready pool of Jamaican (and other Caribbean, and Mexican) labour to replace discontents undermined any real attempt at resistance. ${ }^{222}$

\subsection{The CSAWP Pilot}

The CSAWP emerged in another moment of social and economic crisis for Jamaica. Jamaica gained independence from Britain on August 1, 1962, but the political 
victory was overshadowed by pressing economic problems. Unemployment hovered between 25 and 50 percent, "depending on whether you counted farmers selling homegrown mangoes in front of their shacks and women peddling patties from road-side stands as unemployed."223 Global expansion of sugar production and the 1962 expiry of the International Sugar Agreement, which stabilized world market prices, halved the price of sugar from four to two cents per pound and renewed the threat of financial ruin for Jamaica's long-suffering sugar plantations. ${ }^{224}$ The chaos of sporadic riots by the unemployed was compounded by rounds of strikes that shut down public services and private businesses alike. ${ }^{225}$

Despite the end of colonial rule, Jamaicans saw these problems in familiar terms. Birth control and family planning emerged as an important part of the new government's social policy, reflecting earlier Malthusian concerns about working class sexuality, overpopulation and social disorder. ${ }^{226}$ Squatters, primarily "young people fleeing the rural areas, seeking the bright life of the city" occupied an expanding series of shanty towns in West Kingston, which were quickly associated with crime, gang violence and poverty. ${ }^{227}$ As with the overbreeding poor or peasant farmers 'refusing' work on plantations, squatters' behaviour was characterized as irrational, irresponsible or immoral. Stories abounded of men and women who "left idle land" in the country or 
abandoned jobs and family to live in the shanty towns. ${ }^{228}$ A Daily Gleaner editorial proclaimed that:

there are amongst [the squatters] a great many people who have deeply ingrained anti-social patterns which make them refuse to pay rent normally, even when they can afford to pay, and impel them to "capture" land and goods from other sections of the community, because that is the way they think they should live. ${ }^{229}$

Migration was still viewed as key to the island's economic fortunes, but developments in the 1960 s threatened Jamaicans' access to employment abroad. The passage of the UK's Commonwealth Immigration Act in 1962 significantly restricted migration from current and former British colonies. ${ }^{230}$ Additionally, political pressures in the United States resulted in significantly fewer Jamaicans being recruited for the $\mathrm{H} 2$ program. Willard Wirtz, Labor Secretary under Presidents Kennedy and Lyndon Johnson, effectively killed the Mexican Bracero program in 1963 due to its associations with illegal immigrants, corruption in the recruitment process and abusive labour practises. Caribbean liaison officers had successfully persuaded Wirtz that there were no similar problems in the $\mathrm{H} 2$ program, but concerns over domestic unemployment meant that the Department of Labor was increasingly unwilling to certify farmers' requests to recruit foreign workers throughout the 1960s. ${ }^{231}$ In the summer of 1965, the number of Jamaicans employed on US farms shrank from 8500 to just $600 .^{232}$

The zeal with which the new government fought to retain overseas jobs demonstrates how ingrained migration had become as a solution to Jamaica's social and

228 "House Continues Squatter Debate" The Daily Gleaner, July 28, 1966

229 "Operation Bulldozer"

230 Satzewich 1991: 153.

231 Hahamovitch: 145.

232 Editorial, "Half a Loaf", The Daily Gleaner, August 25, 1965. 
economic problems. Despite the harsh working conditions of Florida sugar plantations, the Jamaican government and the National Workers Union each sent delegations to Washington in the spring of 1965 , appealing to Wirtz and the AFL-CIO to save the H2 program, emphasizing the "mutual economic benefits" of the program. ${ }^{233}$ Hahamovitch contends that Jamaican Prime Minister Donald Sangster raised the specter of the Cuban Revolution, arguing that the loss of $\mathrm{H} 2$ jobs could affect Jamaica's political stability. ${ }^{234}$ A Daily Gleaner editorial lamenting the job cuts argued that "even these lower wages [from the $\mathrm{H} 2$ program] are welcome as relief to our unemployed," and that part of the value of the program was that "the work helps to train our workers in farming skills."235 The specific utility of those farming skills was not made clear. But while racist discourses on population and work had vanished from public forums, the essential problematic remained the same: overseas labour was necessary for social harmony and moral uplift on an island overburdened by 'irresponsible' poor.

The British Colonial Office had been lobbying Canada to accept Caribbean farm labour since at least 1947, in response to postwar restrictions on Caribbean immigration to the UK. Similar overtures were made by the Jamaican and Bajan colonial governments in 1952 and 1954 , respectively. ${ }^{236}$ Such requests were supplemented by pressure from Canadian farmers, particularly from Southern Ontario, throughout the 1950s. The appeal of Caribbean labour to Canadian farmers likely came from the experience of their counterparts in the United States. Satzewich recounts that Canadian

233 "Shearer Leaves on Farm Work Mission", The Daily Gleaner, March 22, 1965; "Farm-Worker Scheme: NWU Appeals to AFL-CIO", The Daily Gleaner, March 22, 1965.

234 Hahamovitch: 149

235 "Half a Loaf"

236 Satzewich 1991: 147. 
farmers used strategies similar to those of the American lobby that initiated the Bracero and $\mathrm{H} 2$ programs. ${ }^{237}$ Farmers insisted that domestic labour sources were insufficient and unsuited to the labour required. Ironically, the characterization of Canadian workers as lazy, undisciplined and troublesome shared features with Jamaican elites' own complaints about the workers Canadian farmers were so anxious to import.

The Canadian government resisted these overtures, first by denying the existence of labour shortages, then by blaming Canadian farmers for creating their own problems by offering insufficient wages and poor work conditions. ${ }^{238}$ But informal talks between farmers and the Jamaican government sought to coordinate appeals and overcome bureaucratic resistance. In 1964, Ivo de Souza of the Jamaican High Commissioners Office met with an enthusiastic group of farmers from Niagara to discuss the possibility of extending the contracts of Jamaicans already in the United States on the $\mathrm{H} 2$ program, so that they could migrate briefly to Canada for more work. ${ }^{239}$ The farmers in turn requested permission from the Canadian government to enact the scheme, but were rebuffed.

Satzewich contends that an auspiciously-timed article in London's Financial Times at last embarrassed the Canadian bureaucracy to action. Published shortly before the Prime Minister's appearance in London for a Commonwealth Prime Minister's meeting, the article castigated Canada for "racial discrimination" in its refusal to admit Caribbean labour. ${ }^{240}$ The Canadian Department of Labour conducted a survey of 
southwestern Ontario that summer, to verify local farmers' claims of a labour shortage. ${ }^{241}$ The following spring, Canadian bureaucrats were in Jamaica to discuss the recruitment of Jamaican workers. The day the Canadian delegation arrived in Kingston, "a mob of men who said they wanted work" stormed a number of government buildings and the headquarters of the Bustamente International Trade Union. A number of public servants were hospitalized, and one man was fatally shot. ${ }^{242}$ The importance of the negotiations for Jamaica could hardly have been made more clear.

Three days of talks covered employment conditions, minimum wages for participants and the administrative processes that would govern the program. ${ }^{243}$ Given Jamaica's experience with the $\mathrm{H} 2$ program, and the previous interest of Canadian farmers in replicating that program, it is hardly surprising that the Canadian arrangements closely resembled the US model. Strangely, after decades of pressure by Canadian farmers, initial participation in the programme was lackluster. The Canadian government expected requests for between 800 and 1000 workers, but by June of 1966 they had only received 104. Farmers cited the high costs of transportation as explanation for their reluctance. ${ }^{244}$ In the end, 263 Jamaicans were selected, all bound for fruit and vegetable farms in southwestern Ontario.

\subsection{Conclusion}

Jamaicans have a long history of labour migration, but it is an oversimplification to attribute this to a persistent, structural 'labour surplus.' For much of the nineteenth century, Jamaica's poverty and poor economic performance was blamed on persistent

241 "Probing Need for Jamaican Labour on Canadian Farms", The Daily Gleaner, July 1, 1965.

242 "Mob Rampage in City" The Daily Gleaner, May 3, 1966.

243 "Agreement in Principle" The Daily Gleaner, May 7, 1966.

244 Satzewich 1991: 171. 
labour shortages. Even as the mass migrations of the 1880 s and 90 s were underway, planters were importing indentured labour from India to work the sugar fields. This understanding of Jamaica's economic problems was itself grounded in imperial assumptions that Jamaica was destined only to be a source of sugar for British markets. Alternative economic models, such as that contained in the Underhill Letter, were utterly dismissed.

Jamaica's migratory movements are better explained by its particular experience with the abolition of slavery, the plantation economy and concerns over the moral regulation of the poor. Racist and classist post-Emancipation discourses about 'lazy', 'irresponsible', 'degenerate' Jamaican peasants emerged from the challenges of persuading the freedpeople to work the estates once they had acquired farmland in the interior, and the difficulties of Christianizing them. The moral value of wage labour, capital accumulation and the nuclear family were seen as key to Jamaicans' redemption as "respectable subjects". These discourses would re-surface periodically in moments of social and economic crisis, entrenching overseas labour migration as a tool of population management. Exporting workers removed troublesome elements of the population and provided them with the work deemed necessary for their moral redemption.

The history of Jamaican labour migration demonstrates the persistence of colonial ideas about race, class and labour in the modern state. It also demonstrates how colonial patronage has created and structured migration programs. The institutionalized migration programs of the twentieth century, the $\mathrm{H} 2$ and the CSAWP, rely on bilateral state relationships between Jamaica and the labour-receiving country. These relationships are predicated on neocolonial paternalism as much as they are about solving mutual 
economic problems. Donald Sangster's invocation of geopolitics and the H2 program's importance to Jamaican political stability in his appeal to the United States is demonstration of this. Canada has its own history of neocolonial patronage in the AngloCaribbean, which is the focus of the next chapter.

\section{Chapter: Canada-Caribbean Transformations: Migration,}

\section{Neocolonialism, and Development}

\subsection{Introduction}

In July 1966, the heads of government of Canada and thirteen Anglo-Caribbean territories $^{\mathrm{iii}}$ met in Ottawa to discuss areas of mutual concern and to lay the foundation for a new regional relationship. The Caribbean Commonwealth-Canada Conference came at a pivotal moment in the decolonization of the Anglo-Caribbean. Only a few years prior, the Federation of the West Indies had dissolved amid internal political conflicts. Jamaica, Guyana and Trinidad and Tobago were newly sovereign states--in the case of Guyana, by a matter of weeks. Barbados was widely expected to gain independence within a year and the various islands of the Eastern Caribbean were soon entering negotiations with Britain on new constitutional arrangements expected to give them internal sovereignty. Canada had substantial and longstanding interests in the Caribbean; the country had strong incentives to see the region remain a safe and hospitable destination for Canadian capital, trade and tourists. ${ }^{245}$

The conference is an excellent demonstration of how neocolonial objectives were pursued in the changing regime of post-colonial international government through the 
logic of 'development', and how temporary migration schemes fit into that logic. The CSAWP had already begun on a pilot basis when the conference opened, as a bilateral program between Canada and Jamaica. In that respect the main development of the conference was a promise to expand the program to the Caribbean states attending the conference if the pilot was successful and labour shortages persisted on Canadian farms. The analytical significance of this conference is its presentation of migration as part of the "aid and trade" agenda of international development. The most important issues to Caribbean delegates, revitalizing the sugar industry and increasing the migration of lowskilled Caribbean workers to Canada, both reflected a concern about 'surplus' population. This 'surplus' was not defined in absolute terms, but according to citizens perceived utility to the development project: Caribbean governments were just as anxious to retain their skilled, educated citizens as they were to shed their poor, unskilled workers. Finding outlets for this unskilled 'surplus' population was now understood as a problem of national economic development in addition to a problem of social stability, reflecting a changing political rationality from imperialism to developmentalism.

The chapter will begin with a critical survey of existing scholarship on the conference. Then, using archived files from the Ministry of External Affairs and scholarship from Laura Macdonald, I will explore the congruities between Canada's development project in the Caribbean and the preceding British imperial project. In this light, I will discuss certain key policy objectives and accomplishments of the conference: a Canadian commitment to waive tariffs on West Indian sugar and new opportunities for migration to Canada through an enlarged domestic help scheme and the promise of a seasonal farm labour program. Although the conference agenda ranged through many 
aspects of the Canada-Caribbean relationship, migration and trade (in particular the sugar question) represented the most complex and contentious issues under discussion. ${ }^{246}$ I argue that the ways in which these issues were resolved at the conference demonstrate the neocolonial role the Pearson government was fashioning for itself in the decolonizing Caribbean, consciously seeking to take over some of Britain's responsibilities in the region. At the same time, the way this role was expressed reflects a changing rationality of international government wherein direct colonial control was no longer seen as a legitimate way to govern. The language of 'development', using aid and trade to govern dependent territories, replaced the language of empire, but the goals and logic of rule remained fundamentally the same.

\subsection{The Conference in Existing Scholarship}

The conference has not attracted much attention from scholars up to now. The common conclusion is that the conference was a personal project of Prime Minister Lester Pearson, carried out over the reluctance and foot-dragging of the participating Canadian ministries. ${ }^{247}$ André claims that Canada first proposed the CSAWP to Jamaica during the conference, but this is not quite accurate. ${ }^{248}$ The pilot program that saw 263 Jamaicans hired for work on Canadian farms was negotiated bilaterally in Jamaica in May of $1966 .{ }^{249}$ At the July conference, Canada promised to permit other Caribbean

246 LAC, "Memorandum for the Prime Minister re: Commonwealth Caribbean-Canada Conference:

Organization of Discussion" June 23, 1966, RG25 vol 9122, File 20-4-CCCC-1, vol. 2. 247 Satzewich 1991: 132; Donaghy and Muirhead: 286-287. 248 Andre: 265. 249 "Canada-Jamaica Farm Labour Talks: Agreement in Principle" The Daily Gleaner, May 7, 1966. 
countries to join the program, "if the experiment proved successful and there was a continued need for outside labour in future years." ${ }^{250}$

Satzewich has examined the Department of Citizenship and Immigration's preparations for the conference to demonstrate that, despite public claims that Canada had "de-racialized" its immigration policy after 1962, state officials remained privately concerned about admitting "'racially' different" people as immigrants. ${ }^{251}$ In the context of the conference, Satzewich focuses on the reluctance of Canadian officials to include migration on the agenda or to significantly open migration channels. Citizenship and Immigration officials proposed numerous strategies to defuse expected complaints from conference delegates that West Indians were being discriminated against in Canadian immigration policy. A limited number of Caribbean migrants were already being admitted to Canada as domestic servants; as this avenue was not extended to workers in other Commonwealth territories such as India and Pakistan, the program was to be highlighted as proof of the already 'favourable' immigration position of Caribbean countries. Canada's bias towards white settlers was also to be compared to proposed Caribbean policies of 'easing out' white residents in newly independent territories, in an attempt to dislodge Caribbean delegates from the moral high ground on race and immigration. If neither of these arguments placated Caribbean governments, it was proposed that Canada should offer to expand the domestic labour program as a concession. ${ }^{252}$

250 LAC, "Commonwealth Caribbean-Canada Conference Final Communique", July 8, 1966, MG $26 \mathrm{~N}$ volume 40.

251 Satzewich 1991: 128-129.

252 Ibid: 131-132. 
Caribbean delegates were apparently not impressed by this reasoning, as Canada did commit to doubling its quota of female domestic workers from 250 to 500 . But even this manoeuvre was a diplomatic sleight-of-hand; Canada was already admitting 400 such workers annually - the actual increase was significantly less than promised and the Canadian government used the higher numbers to negotiate greater control over candidate selection. ${ }^{253}$ As Satzewich notes:

The position taken here highlights a dialectic of economic rationality and ideological determination. Despite an almost 'unlimited demand' for female domestic labour, the Department was keen to maintain control over the migration and ensure that it did not get too large. In fact, it was willing to go against the interests of middle-class Canada for a cheap source of domestic labour by allowing the entry of only one hundred more female domestics each year. ${ }^{254}$

The ideology limiting the expansion of migration, Satzewich contends, was racism. Public officials expressed their reticence to admit West Indians to Canada based on their perceived inability to "readily [adapt] to the Canadian mode of life which, to no small extent, is determined by climactic conditions." ${ }^{255}$ A position paper prepared shortly before the conference argued that too rapid an influx of racialized immigrants would create social disruptions and undermine public support for non-white immigration. ${ }^{256}$ Satzewich notes strong similarities between 'modern' assessments of "West Indian character" and the racial stereotypes that emerged from Caribbean slave plantations in the eighteenth century. ${ }^{257}$

253 Ibid: 141. 254 Ibid: 142.

255 "Immigration by Discrimination", The Black Worker, March, 1952. Quoted in Satzewich 1991: 127.

256 Ibid: 134.

257 Ibid: 136, 144. 
Greg Donaghy and Bruce Muirhead have examined the conference as part of postwar Canadian interest in Caribbean development following a long period of complacency, beginning in 1956 with a British request to provide financial assistance for an emerging Federation of the West Indies. ${ }^{258}$ This change, they argue, was motivated by Cold War geopolitics, specifically "the need to compete with Moscow for friends among the newly independent countries of the collapsing European empires", desire for another stable Commonwealth country in the Americas to "help offset Canada's exclusive continental relationship with the United States" and a belief that properly designed aid could be a stimulus for the domestic economy. ${ }^{259}$ Both the Diefenbaker and Pearson governments nurtured a growing program of development assistance to Caribbean states and British dependencies. The 1966 conference was intended as the culmination of this new relationship, but although it was hailed as a success, Canada's lack of meaningful follow-up led to declining trade and fading diplomatic relations over subsequent decades. ${ }^{260}$

There are two principal shortcomings to this literature. The first is its lack of attention to the goals and aspirations of the Caribbean delegations. Part of this is a question of scope; the focus of the literature is an analysis of Canadian policy, but the unintended effect of this is to portray the Caribbean governments as the passive recipients of a Canadian agenda. Donaghy and Muirhead are particularly prone to this; nowhere do they discuss the reaction of Caribbean governments to Canadian policy or initiatives. Satzewich discusses the tension between Canada and the Caribbean states regarding 
Canadian immigration policy, but his analysis of the conference lacks nuance in two key areas. First, he homogenizes the demands and reactions of the various delegates as aunitary "Caribbean" response. In fact, looking through the conference files it is clear that Caribbean delegations had their own, often conflicting, approaches to the agenda, migration included. Of particular note is the rivalry between Jamaica and Trinidad and Tobago against "the Little Eight" islands of the Eastern Caribbean, which had only a few years prior led to the dissolution of the Federation of the West Indies. ${ }^{261}$ Second, Satzewich characterizes the impasse over Caribbean-Canada migration as a conflict over numbers, without considering what kinds of migrants Caribbean governments wanted to encourage and why. He concludes that Caribbean delegates were duped by modest Canadian concessions on the importation of domestic servants. ${ }^{262}$ This presumes a gullibility on the part of Caribbean leaders, some of them veterans of successful anticolonial nationalist movements, that is difficult to accept. A more sound explanation of why Caribbean leaders were so pleased by such minimal promises lies in connecting migration to the broader problematic of 'development'.

The second shortcoming is an issue of focus, not omission. Satzewich, Donaghy and Muirhead identify two important ideological currents shaping Canadian policy towards the Caribbean, and the global South more generally, when CSAWP was first implemented: respectively, racism and the project of 'development,' particularly as it pertains to Cold War geopolitics. But both analyses consider these currents largely in isolation. Macdonald argues that these concepts are in fact interrelated, derived from

261 LAC, "Conference of Heads of Government of Commonwealth Caribbean Countries, Bridgetown, Barbados: Notes on Questions to be Discussed at Commonwealth Caribbean-Canada Conference", june 14, 1966, RG25 vol. 9123, File 20-4-CCCC-1 vol 1.

262 Ibid: 144. 
Canada's privileged position in, and experience with, the British Empire. ${ }^{263}$ Satzewich characterizes racism as an exclusionary ideology that constructs and maintains hierarchical social divisions. ${ }^{264}$ Macdonald, however, notes a certain productive function in British racial ideology, centered on the problem of governing so-called "subject races." The assumption of the "white man's burden" as articulated by Rudyard Kipling and echoed by Canadian author George Parkin not only affirmed white 'superiority' but was a redemptive endeavour for the imperialist, in danger of becoming "soft," as a result of their own success. Macdonald connects this imperial project with the postwar enthusiasm for development, arguing that while "the terminology used to describe those who were to be 'uplifted' shifted away from the 'weaker races' to the 'poverty-stricken', the sentiment that Canada would thus confirm its own moral superiority remained largely unchallenged." 265

Macdonald draws on a post-colonial critique of development, predicated on a postwar shift in Orientalism from a broadly intellectual perspective to a rationalized, policy-oriented ideology legitimized through the intellectual weight of the social sciences. ${ }^{266}$ Although the racist language of social darwinism and imperial domination "became socially and politically unacceptable," the ideologies of nonwhite inferiority measured against the self-referential European hierarchies persisted, finding new expression in the project of aid and uplift to impoverished postcolonies. ${ }^{267}$ To the neoMarxists the rhetoric of 'development' is instrumental to a self-serving project of

263 Macdonald: 118.

264 Satzewich 1991: 50 .

265 Macdonald: 118.

266 Ibid: 124.

267 Ibid: 125. 
advancing metropolitan commercial interests. Donaghy and Muirhead suggest this at least partially motivated Canadian aid programs. ${ }^{268}$ But as Macdonald points out, echoing the work of James Ferguson and Wolfgang Sachs, 'development' experts and Northern states can and do genuinely believe in the altruism of their rhetoric. The problem actually lies with the technocratic and racist way that development is conceived, privileging metropolitan knowledge and models as both the means and ends of meeting the needs of (de)colonized peoples. ${ }^{269}$ As such, the Canadian enthusiasm for 'development' in the Anglo-Caribbean, despite an apparently legitimate belief in its aims, is an extension of the British colonial project.

\subsection{The Conference: Neocolonialism and Development}

The interplay between development and empire is clear from Pearson's public statements at the conference, and in Cabinet policy deliberations beforehand. A cabinet memo spelling out Canadian policy objectives and positions on the conference agenda justifies the conference in terms of an historical "special relationship" to the Caribbean, emphasizing longstanding trade and investment ties, and the movement of "tourists, businessmen and students" against the backdrop of regional "constitutional changes" that heralded the emergence of a number of independent states and growing autonomy for Britain's remaining dependencies. Moreover, the Commonwealth Caribbean's size and proximity to Canada was seen as "making it possible to for substantial results to be obtained with the kind and size of effort which Canada is capable of making." 270 Canadian policy objectives were centered on strengthening diplomatic and economic 
links with Anglo-Caribbean territories and encouraging Caribbean "economic and political integration in the Commonwealth Caribbean area which would enhance its stability and hence be in our interests." ${ }^{271}$ Without formally resurrecting the Federation of the West Indies, it is clear that Canadian wishes for the region closely reflected the original British plans for decolonization, and that the strengthening of the CanadaCaribbean relationship was seen as replacing the fading British role in the area. The memorandum expressly states that Canada wished to avoid "the establishment of constitutional links of a quasi-colonial nature", but mutual ties to Britain were clearly emphasized as the glue upon which the Canada-Caribbean relationship was founded and would continue.

Pearson's opening remarks to the conference reflected many of these themes. He presented the gathering as an opportunity to review relationships and "place them on the basis most promising for present and future circumstances", noting the various milestones assembled leaders had reached on the way to statehood. ${ }^{272}$ Trade was emphasized as the basis of these relationships; Pearson noted that the conference opened on the forty-first anniversary of the signing of the Canada-West Indies Trade Agreement, and framed the conference as primarily a space to discuss updating it. However, he also noted the specter of the United Nations Conference on Trade and Development (UNCTAD) negotiations and the Kennedy Round of GATT as international developments that could cast uncertainty on the outcome of conference commitments. This tension reflects the profoundly different world system that had arisen between the original signing of the

271 lbid.

272 LAC, "Prime Minister's Remarks at Opening Ceremony: Caribbean Commonwealth-Canada Conference", July 6, 1966, MG26 N vol. 40, File July 1966. 
Canada-West Indies Agreement and the outset of the conference. The old "preferential" relationships based on imperial paternalism were de-legitimized in a new global regime of trade liberalization and sovereign statehood, requiring new tools for these relationships to be expressed.

Pearson's dinner speech the second night of the conference was a much more conscious appeal to those imperial affinities. His remarks that evening focused on the shared institutional legacy of the delegates, grounded in the common ties of the colonial experience, "good colonial experiences and some not so good":

We have inherited Parliamentary institutions from the British, we have also inherited the instinct for freedom with justice under law. We have inherited the British tradition of public service, of duty to the state; the privilege of serving the state. We have inherited the appreciation of the value of free discussion in decision making, the value of compromise and the wisdom of tolerance. ${ }^{273}$

Economic relationships were glossed over, perhaps a diplomatic choice given the conference was still engaged in contentious trade negotiations. Instead, Pearson talked extensively about the radical, generational transformation "from old Commonwealth, predominantly Anglo-Saxon and white, to the new Commonwealth, predominantly Asian and African and non-Anglo-Saxon in membership." ${ }^{274}$ Despite this change, Pearson emphasized, the Commonwealth Association remained a viable institution because of shared history and mutual recognition of the British imperial legacy.

The complicity between empire and development was made particularly clear in a proposal by Montreal businessman Kenneth Patrick. In a speech to the Rotary Club of Montreal in May 1966 and a written report submitted to the Canadian Prime Minister, 
Patrick argued for the establishment of a monetary and customs union between Canada and the "Little Eight" Windward and Leeward Islands, plus Barbados, in the Eastern Caribbean. Canada would also assume foreign affairs and defense responsibilities for the island, an arrangement similar to the "associated state' status Britain was pursuing for the Windwards and Leewards at the time. ${ }^{275}$ This was not the first time such an arrangement had been considered; another businessman, T.B. Macauley, lobbied heavily to bring the Bahamas into Confederation in the early 1910 s. ${ }^{276}$ Clearly, not much came of either proposal, but Patrick's report circulated among the ministers and senior bureaucrats that formed Canada's conference delegation. In a memo, the conference Secretary General J.R. McKinney, a senior official in the Ministry of External Affairs, indicates that Patrick also corresponded with the Chief Ministers of the Windwards and the Leewards, and that Patrick "appears to be in constant touch with Mr. Pickersgill. ${ }^{. i v 277}$ Appended to Patrick's report is a letter of endorsement, printed in the Montreal Star, from Eastern Caribbean commissioner Owen Rowe. ${ }^{278}$ Himself a staunch advocate of an Anglo-Caribbean federation (if not necessarily with Canada), McKinney opined that Patrick had "a genuine and intelligent interest in the problems of the area....Certainly there is now a rather large head of steam behind his proposal."${ }^{279}$

Patrick's justification for union with the Little Eight mirrored many of the Canadian government's justifications for the conference. Union with the Little Eight, he argued, would restore Canada's "reputation as a 'do-something nation' in foreign affairs",

275 LAC, K.R. Patrick, "A Proposal for a New Canada/West Indies Relationship" June 23, 1966, RG25 vol. 9122, File 20-4-CCCC-1 vol 2. 276 Macdonald: 119.

277 LAC, J.R. McKinney, "Memo to A.E. Ritchie" June 17, 1966

278 LAC, "Proposal for a New Canada/West Indies Relationship".

279 LAC, "Memo to A.E. Ritchie" 
a reputation which he believed had been steadily eroding since the Suez crisis because Canadian efforts and influence were spread too thin over projects too large for them to have substantial results. Focusing aid efforts on the Little Eight, he argued, would provide "an area of concentration....which, by its nature, geography and size presents a manageable problem for Canada. ${ }^{280}$

Patrick represented the islands as good 'partners' for Canada along similar lines to Pearson's remarks on the shared bonds of the Commonwealth:

The eight islands have elected responsible government in accordance with the finest of democratic traditions. The rule of law, a basic pre-condition for safe investment, is one of the central features in West Indian life and has prevailed in the West Indian Islands, for the most part, since the early 17thcentury. Indeed on some of the islands such as Antigua and Barbados only the British judicial system has ever been known. ${ }^{281}$

The problem for the islands was that British decolonization was creating "a political vacuum in the Eastern Caribbean", one which Canada was both well-positioned and morally obligated to fill. "They [governments of the Little Eight] are confronted with an awesome task of trying to upgrade the economic welfare of their people and they wimply [sic] cannot do it alone. In recent history NO country in their position has been able to accomplish such a miracle unaided." ${ }^{282}$

To assist in this 'awesome task', Patrick proposed that Canada provide $\$ 200$ million in development funding over ten years, mostly through the provision of 'soft' loans, "accompanied by technical advice and expertise from Canadian governmental agencies. ${ }^{1283}$ In return, through participation in a monetary union with Canada, the

280 LAC, "Proposal for a New Canada/West Indies Relationship".

281 Ibid: 7.

282 Ibid: 21 .

283 Ibid: 18. 
islands would primarily provide fresh agricultural products that "we probably forget that we are capable of producing....in Canada only a few weeks a year," and access to a tropical tourist destination. ${ }^{284}$ These represented economic activities Canadians (by Patrick's reckoning) were already spending more than $\$ 800$ million on annually.

Every single dollar we spend today - 'to seek the sun' as tourists or to buy agricultural produce abroad - is a drain on our balance of payments position. It is self-evident that Canada has much to gain if a significant part of this sum is spent in a Canadian dollar area. ${ }^{285}$

Even if it was never officially pursued, the Patrick proposal is striking as an attempt to update the old imperial project with a new language of development and economic partnership. In becoming an imperial patron of the "Little Eight", Canada would be enhancing its prestige and moral superiority on the world stage, but the 'civilizing mission' of earlier colonial endeavours was laid aside in favour of a project to uplift the islands economically. Indeed, part of what made the islands so attractive to Patrick was the prior success of Britain's influence on 'civilization.' The islands were expected to retain control over their domestic politics; Canada's power over the region was to be expressed through mediating their external affairs and economic 'advice' over how to spend the funds the islands would be loaned under the scheme. The plan speaks to the growing legitimacy of international interventions through "trade and aid", eclipsing direct political controls - indeed, a Montreal Star editorial praising Patrick's initiative expressed West Indian reaction along those very lines:

Naturally, island leaders are enthusiastic about the undertaking. They may be somewhat less interested in Mr. Patrick's customs and monetary union proposals, and probably much less in the thought that we might look after their foreign representation. ${ }^{286}$ 
His proposal contains some peculiar ironies, however. The first is that he advocates the use of Caribbean farm land to supply Canadians with fresh fruits and vegetables, even as Caribbean labour--as seasonal workers on Canadian farms---was being recruited for that purpose. The other is that his analysis of Canada-Caribbean trade contains practically no mention of sugar.

\subsection{Sugar and the Labour Surplus}

It is impossible to overstate the significance of sugar to the Caribbean. The sugar plantation and its reliance on coerced labour was crucial to the pace and character of colonization in the eighteenth century. As discussed in the last chapter, the sugar industry held economic and political significance in the islands throughout the nineteenth century and into the twentieth. Into the 1960s, sugar accounted for twenty percent of Caribbean exports (on some islands, as much as ninety percent) and employed fifteen percent of the labour force. ${ }^{287}$ The industry was in serious decline, but its economic--and political--influence in the region remained strong. McKinney cautioned the Canadian government that it must "sleep, eat and think sugar if the trade discussions are to have a happy outcome." 288 The final report of the conference Trade Committee indicates that the sugar trade dominated discussion, and yielded one of the few firm commitments resulting from the discussion: the extension of a tariff-free quota for Commonwealth Caribbean sugar "equal to the average volume of Commonwealth Caribbean sugar sales

286 Ibid: 29.

287 LAC, "Sugar (A Background Paper Prepared by Canada)" June 16, 1966, RG25 vol 9122, File 20-4CCCC-1 vol 2: pp 3-4.

288 LAC, J.R. McKinney, "Impressions of West Indian Leaders and Their Attitudes Towards the Conference", June 10, 1966, RG25 vol 9123, File 20-4-CCCC-1 vol. 1: 1. 
to Canada over the past five years. ${ }^{289}$ Such a promise meant more to Caribbean governments than preferential trade ties; it also addressed the longstanding issue of the Caribbean 'labour surplus' and resultant problems with social and political stability.

The sugar trade was historically a key linkage between Britain's imperial dependencies. Under the Commonwealth Sugar Act, Britain subsidized the Caribbean sugar industry by buying a guaranteed quota above the world market price. ${ }^{290}$ Canada had established preferential tariff rates on Caribbean sugar in the Canada-West Indies Trade Agreement, and with other Commonwealth producers in $1932 .^{291}$ Nevertheless, the emergence of new sugar producers was depressing world prices and changed the Commonwealth from a "net sugar deficit region" into one of "net sugar surplus". 292 Caribbean producers, facing increasing competition even within the Commonwealth, were pushed into crisis as their share of the Canadian market dried up.

The decline in trade had two key political ramifications. The first impacted Canada's "special relationship" to the Caribbean, as McKinney noted in a pre-conference report on Caribbean attitudes towards the conference agenda: "to lose [market share] to Australia is a pity, but to be edged out by South Africa - an apartheid state - is an insult and they think Canada should recognize it as such." ${ }^{293}$ The other was the threat of a worsening 'labour surplus':

They could reduce their costs by mechanization but over-population on the land is such that they cannot do it without creating mass unemployment. In Barbados, for example, it is illegal to use sugar harvesting machinery. ${ }^{294}$

289 LAC, "Commonwealth Caribbean-Canada Conference: Final Communique", July 8, 1966, MG26 N vol 40, File July 1966: p. 6.

290 LAC, "Impressions of West Indian Leaders": 1.

291 LAC, "Sugar": 3.

292 Ibid.

293 LAC, "Impressions of West Indian Leaders": 2. Original emphasis 294 Ibid: 1. 
McKinney made it clear that the crisis was more dire for the small islands of the Eastern Caribbean than for larger states like Jamaica or Guyana, whose economies were comparatively diversified. But two communiqués from the High Commission in Kingston make it clear that an extension of the protected sugar market would be crucial to defusing social and economic crises throughout the Caribbean. A memo dated May 25th, 1966 outlines Jamaica's economic situation describing growing mining and tourist industries, contrasted with more pessimistic outlook "in the two traditionally gloomy respects of food production and people production."

An interesting table on Page 39 of the Economic Survey shows as graphically as anything how the net increase in population is intimately related in inverse proportion to net emigration and remains at a frightening level for a country with the limited area of Jamaica. Meanwhile, the sugar industry is a long way from having solved some of its fundamental ills that make it such a poor international competitor despite the underpinning of British preferences. $^{295}$

The other is a cable passing on intelligence from the Assistant General Manager of the

Kingston branch of the Bank of Nova Scotia:

He has been in on "sugar situations" recently where he was startled to find Jamaican govt overly willing to bail out individual producers. He said this willingness was based on apparent govtl belief here that special arrangements are bound to result from ott conference which together with uk special arrangements will be breath of fresh air in sugar industry in Caribbean. ${ }^{296}$

Canada's response reflects an understanding of the social and political significance of the Caribbean sugar trade, an assumption of obligations traditionally undertaken by Britain, and the changing rules of international trade. McKinney advised 
that Caribbean leaders, particularly the small islands, would press for either Canadian participation in the Commonwealth Sugar Agreement, or the negotiation of similar quotas that would guarantee Caribbean producers a share of the Canadian market. But such an approach, he acknowledged, was bound to run afoul of GATT obligations. ${ }^{297}$ Waiving existing tariffs for a given quantity of sugar, by contrast, created a new preference for Commonwealth Caribbean sugar in a manner "more likely to be negotiable internationally than any other discriminatory arrangement for the West Indies....it is not, of course, out of line with the various special arrangements which many countries have governing their trade in sugar." 298

\subsection{Migration and Development}

The migration question was closely connected to the sugar question. Both issues were perceived by Caribbean governments as outlets for 'surplus' unskilled workers; aid to the sugar industry provided jobs at home, whereas migration avenues created work abroad. As discussed in the previous chapter, the Caribbean was facing a crisis regarding outmigration; the British Commonwealth Immigrants Act of 1962 significantly curtailed rights of migration from British colonies and former colonies. Moreover, the $\mathrm{H} 2$ visa program in the United States, which drew temporary workers from throughout the British West Indies, had significantly shrunk as a result of domestic political pressure. ${ }^{299}$ Satzewich notes that Canadian officials were initially reluctant to include migration on the agenda, but it was a contentious issue for Caribbean governments and the Pearson

297 LAC, "Impressions of West Indian Leaders": 2.

298 LAC, "Memorandum to Cabinet: Commonwealth Caribbean-Canada Conference-Sugar", July 4, 1966 , RG25 vol 9122, File 20-4-CCCC-1 vol 2. 299 Hahamovitch: 145. 
government ultimately decided to adopt a more proactive approach. ${ }^{300} \mathrm{JR}$ McKinney warned that Caribbean delegates would make "a long song and dance" about immigration issues.301 The Canadian strategy, as discussed above, was to attempt to deflect criticism about racism in Canadian immigration policy, and offer to increase the migration quota of domestic servants. ${ }^{302}$ But the issue of immigration was not only one of numbers, but of kind.

It was widely acknowledged that Caribbean leaders resented racist Canadian immigration policies that restricted immigration from the islands. As Satzewich and others have demonstrated, a racist logic persisted in immigration policy following the formal abandonment of racial admissibility criteria in $1962 .{ }^{303}$ Caribbean immigrants were trickling into the country by 1966 , but Canada had no immigration offices in the Caribbean, which slowed visa processing and created backlogs. When immigration offices were established in Trinidad and Jamaica in 1967, the Director of the Home Branch of the Department of Manpower and Immigration justified it as a measure to curtail illegal immigration from the Caribbean. ${ }^{304}$ Canada also was actively recruiting immigrants from Europe at the time; no such initiatives were present in the Caribbean. ${ }^{305}$

Caribbean leaders perceived this state of affairs as discrimination against their nationalities; as noted above, there is little doubt that Canadian bureaucrats harboured a

300 Satzewich 1991: 133.

301 LAC, "Impressions of West Indian Leaders": 6.

302 Satzewich 1991: 131-132.

303 Satzewich 1991: 129. See also Nandita Sharma, Home Economics: Nationalism and the Making of

Migrant Workers in Canada, (Toronto: U of T Press, 2006): 147.

304 Satzewich: 1991.

305 LAC, "Press Conference: Commonwealth Caribbean-Canada Conference" July 7, 1966 MG25 N 40, File July 1966: 5. 
racially-motivated reluctance to admit more Caribbean immigrants. ${ }^{306}$ However, it is an error to reduce the position of Caribbean governments to a uniform condemnation of Canadian immigration policy motivated by assertions of racial equality. Caribbean leaders no doubt felt and expressed such sentiments, but their principles were tempered by the social stratification of Caribbean societies, and the goals of national development. The problem of the 'labour surplus' in the islands encouraged outmigration as a tool of social and economic policy, and the frame of 'national development' led governments to encourage certain subjects to migrate, while aggressively trying to maintain others. The "song and dance" that McKinney predicted about migration was about opening migration to Canada for a certain strata of Caribbean society, to quiet domestic social discontent and encourage remittance incomes. ${ }^{307}$ The problem is explained neatly in the cabinet document outlining Canadian policy positions for the conference:

Unfortunately those migrants that are selected [by Canada as immigrants] are the skilled and trained people most needed in the development of their own countries. From the West Indian viewpoint the ideal solution would be for Canada to take a minimum number of highly skilled and a maximum number of their unskilled. ${ }^{308}$

Consequently, Canada's negotiating position at the conference was composed of promises not to recruit skilled immigrants from the region, as well as commitments to expand (however incrementally) the recruitment of low-skilled workers. The decision was made not to establish an immigration office in the region, from which skilled immigrants might be actively recruited. In addition to expanding the movement of domestic workers, the Assisted Passage loan scheme ${ }^{v}$ was to be extended to the Commonwealth Caribbean, and

306 LAC, "Impressions of West Indian Leaders": 5.

307 Ibid.

308 LAC, "Memorandum to Cabinet" June 24: 7. 
Canadians promised to "give the Commonwealth Caribbean priority in movements of temporary workers, provided the 1966 movement of Jamaican workers is satisfactory." ${ }^{309}$

Canada's position was somewhat self-serving, given its stated reluctance to admit Caribbean immigrants. Abstaining from establishing immigration offices in the Caribbean facilitated their foot-dragging on the admission of permanent settlers, and the expansion of temporary movements would give farmers access to Caribbean labour without jeopardizing the demographics of Canada's 'imagined community.' But the convenience of the development argument to the entrenchment of racist immigration policy is not necessarily proof of its insincerity. Moreover, it appears that at least some Caribbean leaders saw the migration question in exactly these terms. At the news conference to close the second day of discussions, the Chief Minister of Saint Vincent, Ebeneezer Joshua, was asked about the day's immigration discussions:

I feel that much is said about skilled labour as opposed to unskilled labour coming to the metropolitan countries as, for example, Canada. We feel that, in due course, in time, that we would need these skills as well, because if the Caribbean area is to become a viable area, we must depend on skills from the area itself, if the unemployment system is to be assuaged or reduced to its minimum. ${ }^{310}$

John Compton, Chief Minister for Saint Lucia, echoed these statements:

It seems that what has been happening over the last two days, some of us have agreed that the press...that certain steps that the Canadian Government is taking and has been taking over the past few years would tend to obviate the need for migration to Canada, because if the volume of the Canadian assistance continues, it would mean that Canada will be providing employment opportunities in the West Indies and that there would not be the all this need, this urge, this pressure for the West Indian population to migrate. ${ }^{311}$

309 Ibid: 8.

310 LAC, "Press Conference: Commonwealth Caribbean-Canada Conference" July 7, 1966 MG25 N 40, File July 1966: 6 .

311 Ibid. 
The cordial tone of these public statements on migration is significantly at odds with the perceived tension leading up to the conference. But Joshua's and Compton's comments reflect a relationship between population, migration and development that coincides with the broader agenda of the conference.

\subsection{Conclusion}

The Caribbean Commonwealth-Canada Conference was an opportunity for Canada to fashion a new role for itself in the Anglo-Caribbean, picking up colonial obligations that Britain was in the process of shedding as colonies became independent and metropolitan migration was restricted. The "aid and trade" conference agenda reflects a new political rationality of 'development' through which the old ways of expressing paternalistic colonial relationships which were unacceptable in the new, liberalized international order. This did not mean an end to the colonial project, but its extension through new means.

Framing their demands in a new language of 'development', Caribbean leaders articulated the problem of 'surplus' population as not only one of social stability, but of structural economic deficiency requiring benevolent metropolitan intervention. Certain social categories were defined as 'surplus' according to their perceived utility to national development: Caribbean governments were as anxious to retain educated, skilled professionals as they were eager to export their unskilled labour force. The key commitments of the conference provided tools with which Caribbean leaders could manage this 'surplus.' The expansion of migration programs for domestic servants and farm workers (the CSAWP) created employment outlets for yet more unskilled labour. The establishment of a new preferential tariff on Caribbean sugar was intended to 
revitalize an industry threatened by global production gluts and increasing mechanization, preserved the jobs of unskilled labourers. In accepting these commitments, Canada replaced Britain (and, to some extent, the United States) as a (neo)colonial patron to the Anglo-Caribbean. The next chapter will examine how Jamaica's social policies internalize the rationality of development in the administration of the Overseas Employment Programme. 


\section{Chapter: Jamaica, the Developmentalist State}

\subsection{Introduction}

The previous chapter discussed how the CSAWP fits into a developmentalist rationality that structures the relationship between Canada and the Anglo-Caribbean. Williams and Larner explicitly identify developmentalism as an international political rationality, but the purpose of this chapter is to examine how the development project structures Jamaica's relationship with its citizens. Just as developmentalism required new ways to express colonial paternalism between the global North and South, the postcolonial developmentalist state acts on citizens to fashion 'modern' subjects in the image of metropolitan values and ideals. In the Philippines, Rodriguez argues that the "labor brokerage state" is the result of a US neocolonial project that had already created

class relationships and worker subjects suited to the requirements of global capitalism. ${ }^{312}$ I argue instead that Jamaica's temporary foreign work programs are part of an ongoing neocolonial project to create these subjects. The Overseas Employment Programme (OEP), which administers CSAWP on the Jamaican end, is not merely an outlet for 'surplus' labour and a source of remittance income. Through various measures to screen and discipline participants, the Jamaican state is engaged in creating subjects better suited to the goals of 'national development': stabilizing rural lifestyles and economies, deterring criminalized behaviours (particularly drugs), and shaping behaviour to embrace normative conceptions of family, work and property that stem from colonial discourses about the Jamaican underclass. This process of subject creation facilitates, and is guided by, the overarching rationality of 'development' pursued by the Jamaican state. 
This chapter begins by examining the rationality of development expressed through the Planning Institute of Jamaica (PIOJ), an agency of the Jamaican Ministry of Finance responsible for developing economic and social policy "to achieve sustainable development for the people of Jamaica." ${ }^{313}$ A cursory overview of the PIOJ's history and function shows the central place that planning, under the rubric of 'national development' occupies in the Jamaican state and its social policy. A deconstruction of Vision 2030, the PIOJ's most recent development plan, shows how the development project repeats many of the old colonial problematic of the rural poor, social unrest and moral degeneracy, reified as social science. I then briefly outline the administration of Jamaica's Overseas Employment Programme. Turning to media and interview evidence, I show how the operation of the program and its ancillary services fits the developmentalist logic at work in Jamaican state planning.

\subsection{Planning and Development}

Long-range social and economic planning was a feature of the Jamaican state even before independence. The PIOJ traces its lineage to the Central Planning Unit (CPU) established by Norman Manley as an agency of the Chief Minister's Office in 1955. ${ }^{314}$ The CPU was responsible to collect and analyze economic data from a range of statistical and research agencies newly established by the Jamaican state, and use this information to prepare a ten year National Plan (1957 - 1967) for Jamaica's economic and social development. The production and implementation of the plan required both

313 Planning Institute of Jamaica website, http://www.pioj.gov.jm/AboutUs/MissionVision/tabid/71/Default.aspx, last accessed July 3, 2012. 314 "A Brief History of the Planning Institute of Jamaica", Planning Institute of Jamaica Website, http://www.pioi.gov.jm/AboutUs/History/tabid/111/Default.aspx, last accessed July 5, 2012. 
collaboration and coordination between Ministries; the CPU served as both the repository of expert knowledge for planning, and the facilitator of interdepartmental cooperation:

The establishment of the CPU was the beginning of the process of significant change in the working of Government Ministries, for it became clear that each agency should undertake its own task in so far as the planning of its programmes was concerned. The Ministry of Agriculture and the Ministry of Education were among the first to establish their own sectoral planning units. The CPU exercised its influence not by wielding authority but by offering advice and assistance to them, as well as by way of its primary function of weaving the policies and programmes of individual agencies into a balanced and consistent national system. ${ }^{315}$

Following independence and the election of a Labour government under Alexander Bustamente, the CPU came under the portfolio of the Minister of Development. In 1972, the CPU was re-established as the National Planning Agency (NPA), which was mandated to manage and coordinate external development aid as well as "social planning with an emphasis on manpower planning, sectoral issues." Developing the next several plans $(1970-75,1978-82)$ increasingly involved consultation with labour unions, the private sector and "other interests." Jamaica entered a long relationship with the International Monetary Fund (IMF) in the 1980s, and NPA planning became linked to monetary stabilization and structural adjustment programmes.

In 1984 the NPA became the PIOJ, under the jurisdiction of the Ministry of Finance and Planning, responsible for the continuous monitoring of Jamaica's economic performance "in order to determine the problems that inhibited economic performance and frustrated the attainment of performance targets. ${ }^{317}$ According to a profile prepared by the United Nations Department of Economic and Social Affairs, "the PIOJ aims to 
interpret decisions on economic and social policy and integrate them into the national development programmes." ${ }^{318}$ Although the publications of the PIOJ are more focused than their predecessors on particular policies or areas of the economy, broader medium and long-range plans continue to be produced. The most recent of these is the Vision 2030: Jamaica National Development Plan, a twelve year blueprint for social and economic development tabled in Parliament in May 2009. 319

The Vision 2030 plan demonstrates how the rationality of development permeates Jamaican social and economic policy. The stated objective of the plan is for Jamaica to reach "developed country status" by $2030 .{ }^{320}$ The foreword to the plan lays out the basic problematic: since independence, Jamaica has "suffered from a number of inadequacies" resulting in low GDP growth, high debt, poverty and unemployment, high levels of violent crime and "uncompetitive industries that produce low value commodities." ${ }^{321}$ Through a consultation process that included public servants, private enterprise, labour unions, 'external' development agencies and 'ordinary citizens', the Institute offers a blueprint to overcome Jamaica's structural difficulties and achieve a vision of "Jamaica, the place of choice to live, work, raise families and do business." ${ }^{322}$

As discussed in the last chapter, developmentalism imagines the world as an international "jigsaw," where nation-states are ranked according to their capacity to provide for their citizens' social and economic welfare. 'Developed' states serve both as

318 "Directory Jamaica: Country Profile", United Nations Department of Economic and Social Affairs, http://unpanl.un.org/intradoc/groups/public/documents/un/unpan027754.pdf, last accessed July 6, 2012. 319 "A Brief History of the Planning Institute of Jamaica", Planning Institute of Jamaica Website, http://www.pioj.gov.jm/AboutUs/History/tabid/111/Default.aspx, last accessed July 5, 2012. 320 Planning Institute of Jamaica, Vision 2030: Jamaica National Development Plan, (Kingston, Pear Tree Press, 2009): vii.

321 Ibid.

322 Ibid. 
models to which 'less developed' ones ought to aspire, and as benefactors helping the 'less developed' states emerge from their structural 'backwardness'. ${ }^{323}$ This is the epistemic frame within which the PIOJ is operating. The social and economic ills that beset the island are described as explicitly national problems based on structural deficiencies, and the consequences (low GDP growth, uncompetitive industries) are presented as weaknesses relative to an implied 'developed' competitor. The vision for 2030 is an improved national standing in the international hierarchy, moving from "a middle income developing country to one which affords its citizens a high quality of life and world-class standards in critical areas. ${ }^{324}$ The Millennium Development Goals (MDG) developed by the United Nations are prominently employed by the PIOJ as a benchmark of Jamaica's development progress, and to measure the success of future initiatives. ${ }^{325}$ The PIOJ also recognizes the role of international partners in the conception and the implementation of Vision 2030, securing 'developed' nations a role as both models and benefactors in Jamaican socio-economic uplift. ${ }^{326}$

To achieve this vision, the planners have established four goals: "Jamaicans are empowered to achieve their fullest potential; Jamaican society is secure, cohesive and just; Jamaica's economy is prosperous; and Jamaica has a healthy natural environment. ${ }^{327}$ Each of these goals is subdivided into a series of outcomes to measure the attainment of each goal, and further into a set of strategies to operationalize outcomes. The nature of these outcomes and strategies are not easily summarized, nor are they all

323 Walters and Larner: 407.

324 Vision 2030: xxii.

325 Ibid: $7-9$.

326 Ibid: $x x x i v$.

327 Ibid: $x v$. 
relevant to my argument. But the overarching focus of the plan is to "create the conditions in which our productive enterprises are able to generate greater levels of wealth, and in which the social and environmental conditions and general well-being of the society are enhanced." ${ }^{328}$

Vision 2030 conceptualizes Jamaica as a series of "capital stocks" representing valuable attributes of the population or physical geography. ${ }^{329}$ Development hinges upon accruing and deploying these capital stocks in a manner that increases national wealth, enabling Jamaicans to purchase and pursue a higher standard of living. Jamaica's fundamental defect is that it relies too heavily on "lower" forms of capital ("natural endowments" of mineral resources and a tourist-friendly climate, cheap labour and land) without taking advantage of "higher", more productive forms (cultural assets, "valueadded" manufacturing, intellectual property and an appropriate national "mindset"). The scarcity of stocks of "higher" capital means that Jamaicans are less productive, their economic activities uncompetitive, and as such their standard of living lags behind that of other countries. Vision 2030 aims to transform Jamaica by building its stocks of "higher" capital through reform of public institutions, investments in health and education, the achievement and maintenance of macroeconomic stability and environmental stewardship. These interventions are intended to enhance the ability of 'natural' processes to facilitate the use of "higher" forms of capital and promote the maximization of national welfare.

Biopolitics ties together many of the disparate interventions and commitments of Vision 2030. A number of outcomes related to the empowerment of Jamaicans "to 
achieve their fullest potential" deals with primary health, disease prevention and food security. ${ }^{330}$ The extension of life, the reduction of infant mortality, and the promotion of good health throughout Jamaicans' lifespan are explicitly related to the extension of a productive working life. Vision 2030 organizes Jamaicans demographically into "youth", "working age" and "elderly" cohorts, noting that population ageing as a result of declining fertility and extended life expectancy will present both a challenge and an opportunity for national development. A 'demographic dividend' is expected to peak in 2025 as the greatest proportion of Jamaicans be part of the "working age" cohort, but thereafter the productive capacity of the labour is threatened as an increasing share of Jamaicans enter old age, with its associated disabilities and health burdens on family and social services. ${ }^{331}$

Likewise, the emphasis on macroeconomic stability and "an enabling business environment" represent attempts to organize Jamaican's material lives through optimized 'natural' economic processes. Vision 2030 advocates reductions in public expenditure and public debt, reforms for a "simple, transparent, efficient, predictable and equitable" tax code, reducing inflation and 'stabilizing' the financial system by securing financial institutions and cracking down on unregulated investments. ${ }^{332}$ Collectively, these interventions are intended to "reduce risk and uncertainty in decision-making by economic actors", facilitating productive economic activities. ${ }^{333}$ Alongside a host of measures designed to create "as competitive a business environment as any country in the 
Caribbean," the intent of the planners is to create a secure, open environment for the circulation of capital through the 'natural' operation of markets. ${ }^{334}$

The plan also clearly resonates with a certain conception of social government. Key to the goal of individual empowerment is the development of "world class education and training," to create Jamaicans not only as skilled, productive workers but contributing members of society. Particular emphasis is placed on education and training opportunities for "unattached youth." ${ }^{335}$ The plan commits to expanded participation in social insurance and the delivery of social assistance to the vulnerable, and to strengthen the rehabilitative capacity of the correctional system. ${ }^{336}$ Without directly intervening in the lives of vulnerable subjects, the state claims a prerogative in directing them to agencies and assistance in minimizing their threat or disruption to society.

What distinguishes developmentalism from liberalism is its keen sense of the place of the nation in the world system. As discussed earlier, Jamaica's development plans are consciously framed according to the metrics and normative forms of 'developed' nations. The forms and processes that shape and evaluate 'development' internationally have been internalized and shape the state's relationship with its citizens. As discussed in the last chapter, colonial civilizational hierarchies have been supplanted in the development project by the abstract principles of social science, but the racism and paternalism remains in place. Perhaps nowhere is this clearer than in Vision 2030's exhortations for a new 'national mindset' crucial to the success of development:

Deliberate steps must be taken to change the mindset of our nation and address traits that are likely to inhibit progress towards our development.

334 Ibid: 139.

335 Vision 2030: 57.

336 Ibid: xvi. 
Core values such as respect, honesty and truthfulness, forgiveness, tolerance, trust, honour, discipline, responsibility, cooperation, good work ethic and punctuality, are essential for transitioning this society to a prosperous one. $^{337}$

In this respect, Vision 2030 embodies what Bogues refers to as the creation of the "respectable black" subject, embodying British-derived middle class values that both justify and define the Creole claim on sovereign citizenship. ${ }^{338}$ Implied in many of these "core values" to be instilled in the population is a 'defective value' corresponding to racist stereotypes of Caribbean people that, according to Bogues, now form middle class stereotypes of the working class. As such, the 'Quashee' caricature remains present in the development plans of the Jamaican postcolony.

\subsection{The OEP and the Formation of "Respectable Subjects"}

Vision 2030 does not mention temporary migration programs as part of its development strategy or as part of the model for a 'developed' Jamaican economy. The "sustained outward migration" of Jamaicans, particularly educated or skilled workers, is

presented as a negative outcome of underdevelopment. ${ }^{339}$ The diasporic "family abroad" is referred to as partners in national development, but the state's goal is ultimately to reduce or eliminate socio-economic pressures to emigrate. ${ }^{340}$ Nevertheless, in other documents the PIOJ recognizes a relationship between migration and its development goals. A PIOJ report on a UN meeting to discuss international migration emphasizes and endorses the importance of migration in "co-development...the coordinated or concerted improvement of economic conditions in both areas of origin and areas of destination 
based on the complementarities between them." ${ }^{341}$ It is possible to describe the CSAWP, at least superficially, o

in exactly these terms: Jamaican structural labour surpluses are used to 'fix' the structural labour shortages on Canadian farms. The Jamaican Ministry of Labour, who are responsible for the administration of temporary migration programs, is mandated to "contribute to national development through the provision of efficient and effective labour and social security services within the context of a globalized economy." ${ }^{342}$ The aspirations and logic of the development project permeate Jamaican state programs and policy well beyond their formal development planning.

Moreover, Vision 2030 raises certain population problems that I have previously argued were integral to Jamaica's embrace of labour migration, as problems of development. Foremost among these is the problem of "surplus population." The plan confirms that curbing population growth has long been a Jamaican policy objective, and sets a target of zero population growth in order to create a "balance between our working age population and those who are dependent." ${ }^{343}$ The plan also posits a link between poverty and social instability. ${ }^{344}$ Training and the provision of "entrepreneurship opportunities" for vulnerable youth are framed not only as a strategy for Jamaicans' individual empowerment, but also in attaining a "secure, cohesive and just" society. ${ }^{345}$ Finally, rural Jamaica is identified as a place of particular "under-development," creating

341 "Report on United Nations High-Level Dialogue on International Migration and Development, United Nations, New York, September 14-15, 2006," Planning Institute of Jamaica website, http://www.pioj.gov.jm/ResearchandData/SocialSectorsReports/tabid/131/Default.aspx last accessed July $10,2012$.

342 Jamaica Ministry of Labour and Social Security website,

http://www.mlss.gov.jm/pub/index.php?artid=32\&par id=32\#VISION last accessed July 6, 2012.

343 Vision 2030: 85; see also 73.

344 Ibid: 59 .

345 Ibid: 108. 
both intensified rural poverty and "uncontrolled" rural-urban migration. ${ }^{346}$ Just as the rationality of development permeates the administration of the OEP, the problematization that first encouraged Jamaica to send workers overseas persists in the development plans of the postcolony. What has changed are the techniques used to resolve the problems raised.

The Overseas Employment Programme is part of the Manpower Services section of the Labour Ministry, and administers four temporary foreign work programs: the CSAWP, known in Jamaica as the Canadian Farm and Factory Programme; the United States Farm Work Programme; the United States Hospitality Programme; and the Guantanamo Bay Programme. ${ }^{347}$ Roughly 6000 workers participate in the Canadian program, and 4000 are employed on US farms. ${ }^{348}$ The US Hospitality program employs approximately 2000 more. ${ }^{349}$ The Ministry recruits and screens separate labour pools for each of these programmes in collaboration with destination country officials. They also administer the Overseas Workers Compulsory Savings Department, a fund which automatically deducts $25 \%$ of workers earnings, to be paid out to them upon return to Jamaica $^{350}$ Liaison services are provided for workers abroad, and special social workers (the Family Services unit) are employed to respond to family situations at home. ${ }^{35 I}$ The liaison officers, as discussed earlier, are responsible for ensuring that workers are

346 Vision 2030: 255.

$347 \mathrm{Ibid}$, http://www.mlss.gov.jm/pub/index.php?artid=32\&par id=32\#THE LABOUR DIVISION last accessed July 6, 2012.

348 Based on 2011 figures. see: Planning Institute of Jamaica, "Economic Sector Indicators 2011: Overview".http://www.pioj.gov.jm/ResearchandData/EconomicSectorIndicators/tabid/124/Default.aspx last accessed July 6.

349 Avia Collinder, "Eyeing Jobs Overseas? - Hopes up for 2010" Jamaica Gleaner, September 9, 2009. 350 Report on the Appropriation and Other Accounts of Jamaica For the Financial Year Ended March 31, 2010 (Kingston, Jamaica: Auditor General's Department, 2010):123.

351 Avia Collinder, "Ministry Ensures Stability for Remittence-Dependent Households" Jamaica Gleaner, February 15, 2009. 
properly treated on site, and for mediating conflicts between workers and employers. They investigate workplace accidents and maintain an insurance fund for the families of workers who die on the job. ${ }^{352}$ Family Services provides a range of counseling and mediation services for families of workers abroad, including referrals into rural development and youth training programs, grief counseling for families of deceased workers, and homework assistance and behavioural counseling for school age children. ${ }^{353}$ Family Services counselors also work with liaison officers to encourage workers to send money home.

Jamaicans are recruited to the programme by receiving "tickets" issued by their local MP. The Ministry has established certain pre-selection criteria which MPs are expected to observe. Candidates must be: between $22-45$ years of age, literate, "of good character and good health", not previously barred from the OEP for any reason, in possession of a certified birth certificate and a Jamaican passport, free of any criminal record or deportation "from any country. ${ }^{354}$ Once in receipt of a ticket, workers are screened by the OEP according to their experience with farm work, medical fitness and (lack of) criminal history. ${ }^{355}$ If they pass the relevant tests, they are entered into a labour pool from which Canadian farmers can hire. Workers remain attached to the farmer who hires them throughout the season; they cannot change jobs without the permission of

352 "Dead Farmworkers' Families Receive Final Compensation" Jamaica Observer, August 2, 2011;

"Charles Awaits Report on Deaths of J'Can Farm Workers" Jamaica Observer, September 13, 2010.

353 "Dead Farmworkers"; Collinder, "Ministry Ensures Stability".

354 "Statement by Minister of Labour and Social Security to the House of Parliament on the USA and Canadian Farm Work Pre-Selection Programmes", http://www.japarliament.gov.jm/attachments/025_STATEMENT-USACANADIAN\%20FARM\%20WORK\%20PROG..PDF last accessed July 18, 2012.

355 Ministry of Labour and Social Security website, http:/www.mlss.gov.jm/pub/index.php?artid=12, last accessed July 6, 2012. 
liaison officers, their employer and Canadian officials. ${ }^{356}$ Repeat participation relies on being 'named' by the farmer that hired them the previous season, and continuing to pass annual medical and criminal screenings. Farmers can be dismiss a worker from their post for any reason and send them home at the worker's expense. The interventions of the liaison service are intended to address the power imbalance between workers and farmers, although it is widely noted that farmers control their workers more or less with impunity. $^{357}$

Remittance incomes are generally acknowledged as the chief benefit of these programs to Jamaica, not only for individual workers and their families, but for the country as a whole. The Bank of Jamaica reports regularly on remittance earnings, and the value of temporary foreign work programs is often measured by media and policy makers based on the dollar value of worker's earnings returned from abroad. ${ }^{358}$ These accumulations of capital are perceived as valuable to sustaining necessary imports and to increasing banks' capacity to lend domestically, growing the local economy through investment. ${ }^{359}$ But the farmwork programme has a utility beyond capital accumulation. The OEP also assists the Jamaican state in disciplining workers and creating subjects that conform to the 'national mindset' outlined in Vision 2030. Janet McLaughlin has made a similar argument about employers, state agents and workers themselves colluding to create 'ideal' workers "who work hard, obey rules, and are completely flexible; they do

356 Foreign Agricultural Resource Management Services website, http://www.farmsontario.ca/program.php?divname- TransferringWorkers last accessed August 15, 2012.

357 Basok 2002: 17; Preibisch: 420; McLaughlin: 80-81.

358 Bank of Jamaica website, http://www.boj.org.jm/publications/publications show.php?publication id=14 last accessed July 9 , 2012; Collinder, "Eyeing Jobs Overseas?"

359 David Mullings, "Mobilizing Diaspora Entrepreneurship and Investment" Jamaica Observer, June 5, 2011. 
not aspire to advance their position, develop personal or romantic relationships, or settle in Canada. ${ }^{360}$ But her analysis is confined to the Canadian worksite; I contend that the same actors also collude in the production of 'ideal' citizens for the developmentalist state. The promise of a livelihood to low-income Jamaicans is a powerful tool to modify individual and community behaviours. The OEP is also a means to discipline the population according to the traits of the idealized 'national mindset' of the development project. It intervenes in the lives of Jamaicans historically perceived as obstacles to economic progress and seeks to reform them as respectable subjects.

The Canadian Farm Work Programme and its US counterpart are perceived by the Jamaican government specifically as a measure for the alleviation of rural poverty, and the maintenance of rural livelihoods. Rural Jamaica, as noted above, is understood as a space of particular underdevelopment: infrastructure such as roads and piped water are poorly-maintained. ${ }^{361}$ Media portrayals of the challenges of rural life emphasize tenuous employment, poor prices for cash crops and difficulties in finding markets. ${ }^{362}$ The precariousness of life in the parishes leads many to migrate to Kingston, by far the largest urban center on the island, which places undue stress on urban infrastructure and services. $^{363}$ Participation in the programme provides small-plot farmers an income to supplement their farm earnings, and to invest in upgrading their farms in Jamaica. Numerous media accounts credit earnings through the OEP as crucial to farmers

360 McLaughlin: 80.

361 Ingrid Brown, "Mi Tired Ah It Now" Jamaica Observer, April 19, 2009; "Sheer Discontent" Jamaica Observer, September 6, 2009; Karen Sudu, "Community Spirit Alive in Wakefield, St. Catherine" Jamaica Gleaner, April 23, 2011.

362 George Henry, "Farming a Life Saver For Many Years", Jamaica Gleaner, April 12, 2007. 363 Vision 2030: 255. 
maintaining their fields and supporting their families. ${ }^{364}$ Ellis Williams, head of the Canadian Farm Work Programme in 2009, further credited the programme as a form of apprenticeship for Jamaican farmers: "The farmers would come back equipped with knowledge and share it with other farmers. Foreign exchange comes into play and they learn how to set up greenhouse farming." 365

The value of the OEP to the project of national development is thus not just providing jobs, but providing jobs that will keep Jamaicans in the parishes, providing income and investment to underdeveloped rural spaces and staunching the flow of ruralurban migration. Participant screening criteria uphold this; prospective participants are expected to list their agricultural experience in application forms, and the medical screening includes a test of the hardness of workers' palms to gauge their experience with manual labour. ${ }^{366}$ Residents of Kingston and "urban St. Andrew" are also barred from participating. ${ }^{367}$ In a 2002 news article, Anthony Irons, the Permanent Secretary in the Labour Ministry, justified such restrictions by saying that urban residents were more likely to abscond from overseas assignments than their rural counterparts. He declined to explain why this was the case, but followed up by saying that the programme "was geared towards farmers, most of whom are from the rural communities. "368

364 George Henry, "Farming is 'Hereditary"', Jamaica Gleaner January 18, 2007; Henry, "Farming a Life Saver"; Sudu, "Community Spirit Alive."

365 Roxroy McLean, "Farm-Work Programme a Blessing to Jamaican Families" Jamaica Gleaner, April $16,2009$.

366 Interviews with "David", "Keith", "Bruce", Kingston and Ocho Rios, December 2011. Only Bruce mentioned the work experience form. See also: Ministry of Labour and Social Security website, http://www.mlss.gov.jm/pub/index.php?artid=12, last accessed July 6, 2012.

367 "Over 300 Abscond - Overseas Hotel, Farm Work Programmes Said Threatened" Jamaica Gleaner, November 11, 2002.

368 Ibid. 
The OEP operates not only to stabilize rural incomes and economies, but to discipline Jamaicans into becoming better "developmental subjects," embracing the reformed 'national mindset' of Vision 2030. This is accomplished through programme screening criteria and the construction of both 'heroic' and 'delinquent' subjects in media narratives and government interactions with workers. Work overseas is held out as both as an individual reward for adhering to a particular lifestyle, and as a contribution to Jamaican "national development." Conversely, control of 'bad' behaviours is justified through their connection to existential threats to the programme.

To qualify for--and remain in--the programme, Jamaicans are expected to prove their medical fitness, their lack of criminal activity, and "ties back in Jamaica, including land titles or other assets. ${ }^{369}$ The justification for this is commonly that Canada is unwilling to admit unhealthy or criminal workers, or workers who will "abscond" from their job assignments to live illegally in the country. Screening requirements were tightened in 2002 and 2006 in response to Canadian concerns over worker desertions and criminal deportations, respectively. ${ }^{370}$ Bruce, one of my interview participants, described health screenings along similar lines:

If you have any sickness at all you cannot enter the programme....if you have AIDS or gonorrhea, you know, everything come up on the test. So if you have AIDS you cannot make it on the programme. Or if you have gonorrhea, can't make it. You can get a 50-50 chance, gonorrhea can cure. But AIDS, they don't want AIDS in their country! $!^{371}$

It is entirely plausible that these criteria reflect actual concerns of the Canadian government. But one can also see how such a screening process requires Jamaicans to 
police their behaviour. To gain access to important employment opportunities, workers must not only perform to their employers' satisfaction in Canada, but must also regulate their sexuality and interactions with the law at home.

The Family Services Unit, established in 2009, extends worker self-regulation to fiscal and social, particularly family, relations. Social workers employed by the Labour Ministry are mandated "to act as liaison officers between farm workers employed abroad and the families left behind in Jamaica." ${ }^{372}$ The unit portrays itself as an agency for the maximization of childrens' welfare, providing counseling and directing workers' relatives as needed into education and rural development programs. But the unit is also closely involved in encouraging workers to send remittances home to families. At times this work involves determining the family ties of overseas workers: "We have discovered that a number of workers who have travelled to the United States listed themselves as unmarried, but in fact they were involved in long-standing common-law unions with a number of children in need of support. ${ }^{373}$ In this respect, the unit is an extension of the moral regulation of the compulsory savings programme, presented as an antidote to "the temptation of our farm workers to be profligate in spending their earnings overseas to the detriment of their families in Jamaica. ${ }^{374}$

The reach of the state into workers' domestic relationships and household finances plays on a common portrayal of migrant workers as providers for their families. OEP participants are frequently portrayed in the media as family men who use the programme

372 Collinder, "Ministry Ensures Stability".

373 Labour Minister Pearnel Charles, quoted in Collinder, "Ministry Ensures Stability". 374 Everton Pryce, "Putting Up Resistance to the Farm Work Programme", Jamaica Observer, June 15, 2011. 
to provide for and educate their children ${ }^{375}$ Beresford Crumbie credited the CSAWP "for giving him the means by which to bring up his nine children." ${ }^{376}$ Omar Clarke, in an interview with the Jamaica Gleaner while waiting for a flight to Canada, explained the importance of being a family provider in terms of a distinctly masculine performance:

I have to provide for my family or somebody else will do it for me....But it's [the work on Canadian farms] not too bad and we have to endure it because a man we name. Me have to send money to my kid to go to school and make my house feel comfortable. ${ }^{377}$

The regulation of family relations through the programme corresponds to Vision 2030 's focus on strengthening "family responsibility" in terms of caring for vulnerable Jamaicans. $^{378}$

Two incidents demonstrate how OEP regulation can extend beyond programme participants, to prospective participants and even the community at large. The first is the growing concern in recent years about the literacy of farm work participants. In recent years, basic literacy has been added as a screening criterion, ostensibly because "workers are now required to use advanced technology in agriculture." ${ }^{379}$ Given the growing number of temporary foreign workers in Canada coming from non-English speaking countries as diverse as Mexico, Thailand, Guatemala and Vietnam, it is unclear how illiterate Jamaicans would necessarily be at a disadvantage in the CSAWP labour pool. ${ }^{380}$ Nevertheless, the Labour Ministry used the opportunity to implore Jamaicans to educate

375 "Why Should the Good Suffer For the Bad?" Jamaica Observer February 15, 2004.

376 "72-Year-Old Farm Worker Still Going Strong in Canada" Jamaica Gleaner, September 6, 2000.

377 McLean "Farm-Work Programme a Blessing"

378 Vision 2030: 86.

379 Dionne Rose, "'Poor Literacy a Setback in Farm Work Selection': Canadian Official Says Females Were More Literate Than Males" Jamaica Gleaner, March 23, 2005.

380 See Kerry Preibisch, "Pick Your Own Labour: Migrant Workers and Flexibility in Canadian Agriculture" International Migration Review 2010,44(2) : 417-18 on the diversity of Canada's temporary workforce. 
themselves. "Don't let anybody tell you that they are not able to read and write because they did not get an opportunity...They must seek the opportunities and educate themselves so they will be in a position to take advantage of these job opportunities. ${ }^{.381}$ Vision 2030, as already discussed, heavily emphasizes education as part of a project of "individual empowerment." Literacy in particular is a key indicator of the Human Development Index, which Vision 2030 employs as a metric of Jamaican development. ${ }^{382}$

A more dramatic attempt to use OEP participation as a community disciplinary tool occurred in 2004, when five men were arrested at the Norman Manley Airport in Kingston, farm workers bound for Canada charged with possession and intent to export liquid cocaine. ${ }^{383}$ The arrests provoked the Labour Minister at the time, Horace Dalley, to introduce stricter supervision of workers as they left the country, including a prohibition on transporting goods other than clothing, and a police escort for workers heading to the airport. Additionally, fewer farm work tickets were to be distributed to MPs in constituencies where the illegal drug trade was prevalent, and residents of Rock River in Clarendon parish, where three of the arrested men came from, were banned from the program for three years. ${ }^{384}$ The ban provoked heated resistance as a breach of "natural justice" from Rock River's MP, Pearnel Charles, who would himself become Labour Minister in 2007. Charles's argument, outlined in a Jamaica Observer article, hinged on Rock River's longstanding reliance on the programme, and the unjustness of associating the community with illegal drugs. ${ }^{385}$ Rock River is painted in the article as a

381 Rose, "'Poor Literacy a Setback".

382 Vision 2030: 21.

383 Petre Williams, "Five Farm Workers Caught With Drugs" Jamaica Observer February 4, 2004. 384 Ibid.

385 "Why Should the Good Suffer For the Bad?" Jamaica Observer February 15, 2004. 
farming community that produces legitimate agricultural commodities such as coffee and cocoa, and populated by farmers with decades of experience in the program. Icelyn James, "a potential farm worker" summed up community and Charles' opinion:

If the Government should stop people from this community from going, people would be greatly hurt and distressed. They would suffer because they depend on it for survival. So I don't think that they should spite the community because of what they said some people did, and cause a lot of people to suffer. ${ }^{386}$

Dalley later rescinded the ban after Charles met with Canadian officials to assure them that "the majority of Rock River residents were opposed to drugs. ${ }^{1387}$ But the other measures, including restrictions on the distribution of farm work tickets, remained in place. When Charles took over as Labour Minister in 2007, he restored the privilege of all MPs to nominate people to the programme, but admonished Parliamentarians to distribute these recommendations carefully: "It will therefore be incumbent on you to ensure that the persons you recommend are of the highest quality." ${ }^{188}$ The incident demonstrates the significance of the programme to rural communities: bans on Kingston residents went apparently unchallenged.

The Rock River incident also shows how the programme can be used to discipline entire communities and reinforce clientelist networks; Rock River's continued participation in the OEP hinged upon presenting itself as a "law-abiding" community to Canadian and Jamaican officials. The distribution of farm work tickets is itself a privilege that strengthens the community standing of people in a position to offer them.

386 Ibid.

387 Dwight Bellanfante, "Dalley Softening Position on Rock River Ban" Jamaica Observer, February 19, 2004.

388 "Statement by Minister of Labour and Social Security to the House of Parliament on the USA and Canadian Farm Work Pre-Selection Programmes", http://www.japarliament.gov.jm/attachments/025 STATEMENT-USA-

CANADIAN\%20FARM\%20WORK\%20PROG..PDF last accessed July 18, 2012. 
As discussed in chapter two, the system was initially designed as a form of political patronage, where tickets went to those whom MPs wanted, or owed, political favours. ${ }^{389}$ Keith, another of my interview subjects, indicated he got his ticket through a former employer who was well-known to his MP. ${ }^{390}$ The denial of farm work tickets to parishes that participated in drug smuggling exerts a similar pressure on communities; those who want to use the programme must not only police their own behaviour, but the behaviour of their neighbours. Similarly, those who want to grant access to the programme as a means to enhance their own community standing must police the behaviour of their clients.

The OEP also regulates participants' behaviour by implicating them in the development project. Workers are continually reminded that their work performance reflects not only on themselves, but on the OEP and the nation itself. Labour Ministers periodically schedule media events to greet groups of farm workers departing for the US or Canada. In speeches for such occasions, workers are commonly told that they are "ambassadors for the country. ${ }^{39 I}$ Pearnel Charles took one occasion to publicly praise the work of Lester Cohen, whose hard work on a farm in the United States allegedly secured a request for 300 more Jamaican workers:

One Jamaican made it possible for you to travel. I understand that five Jamaicans were on a team, and their hard work, discipline and (good) behaviour attracted a farmer and he went to one of them to enquire about where they were from and the farmer made this request because of this one farm worker, Lester Cohen. ${ }^{392}$

389 Hahamovitch: 55 .

390 Interview with Keith, Ocho Rios, December 2011.

391 "First Batch of Farm Workers Leave For Canada" Jamaica Observer, January 8, 2011.

392 Pearnel Charles, quoted in "50 Farm Workers Off to Washington DC", Jamaica Observer, May 5 , 2010. 
The interview with Bruce revealed how these discourses are internalized and circulated through the social networks of program participants:

We have Jamaicans they sitting and they don't want do anything. But we go on the programme and you have to work. If you don't work, you don't have nothing to get. You have to work for what you want. So what we tell them, when we go up there and come back we say the hardest work we do in Canada, go do it boy. ${ }^{393}$

In this sense, Jamaica's programme somewhat resembles the Philippine government's idealizing of migrant workers as "National Heroes. ${ }^{1394}$ But the pageantry of the Philippines' Migrant Heroes Week and other nationalist celebrations of workers is, according to Rodriguez, intended to retain the loyalty of overseas citizens and strengthen their identification with the Filipino nation. ${ }^{395}$ Jamaica's embrace of migrant workers reflects these themes, but it is also an exhortation to embody the values of Vision 2030's idealized 'national mindset':

I am appealing to you this morning to let us keep this programme going and to tell you the programme can only go on based on your performance. A negative performance destroys the programme. A positive performance increases the need for the Jamaican farmer. ${ }^{396}$

In a vigorous public defence of the OEP following the CMAJ scandal, former Labour Ministry official Everton Pryce framed the value of the programme not only in terms of economic or social advancement, but in the moral terms of redemption through hard work:

For the men (and lately women) who participate in it are outstanding ambassadors for Jamaica - drawn literally from the ancestral cane-piece -

393Interview with Bruce, 2011.

394 Rodriguez: 78.

395 Ibid: 79.

396 Pearnel Charles, quoted in "First Batch of Farm Workers Leave For Canada" Jamaica Observer, January 8, 2011. 
who for several generations carry in their sinewed arms and sturdy hearts the hopes and aspirations of their families and communities while toiling overseas, and contributing to the gross domestic product of the "little piece of rock" they call home. Through their collective efforts, children are able to achieve educational attainment at all levels contributing to our stock of professional human resource, decent housing is provided for thousands of families, and entire communities enriched. ${ }^{397}$

The appeal to "national heroes" is intended not just to strengthen the loyalty of overseas workers, but to serve as role models, inspiring national development through adherence to the values of hard work, family responsibility and civic-mindedness.

\subsection{Conclusion}

The development project was integral to the Jamaican state even prior to independence. Since the 1950 s, planning agencies operating in a developmentalist paradigm have occupied a central place in the bureaucracy, specifically mandated to coordinate Jamaican social policy between various Ministries to align with the goals and principles of "national development." My analysis of Vision 2030, the most recent development plan, demonstrates the continuities between modern and colonial understandings of Jamaican economic and social (under)development. Concerns over 'surplus' population, poverty as a source of social instability, rural space as a site of poverty and underdevelopment, and the 'Quashee' stereotype, all problems of colonial government, are reflected in the modern development plans of the state.

The interventions of the OEP, which administers CSAWP on the Jamaican end, reflect attempts to address these development concerns. The programme not only provides employment for Jamaica's 'surplus' labour and remittance income for poor families, but it functions to shape the behaviour of participants, families and their 
communities according to the ideals of the development project and the formation of "respectable subjects". Screening criteria and ancillary social services intervene in workers lives to maintain rural livelihoods and check the flow of urban migration, encourage current and prospective participants to self-regulate their sexuality and criminal behaviour, determine and strengthen their financial ties to family, and identify with and take part in the project of national development. 


\section{Chapter: Conclusion}

In Black Skin, White Masks, Fanon describes the return of the colonized subject

from the metropole as a person transformed:

He can no longer understand Creole; he talks of the Opera House, which he has probably seen only from a distance; but most of all he assumes a critical attitude towards his fellow islanders. He reacts differently at the slightest pretext. He knows everything. He proves himself through his language. ${ }^{398}$

Fanon's central concern in this passage is the privileging of metropolitan culture, language and values that cultivates a sense of inferiority in the colonized. The admiration, and emulation, of the metropole stems from the production of knowledge that reifies metropolitan values as the self-referential metrics of 'civilization.' Colonialism is the production and dissemination of these systems of knowledge amongst the colonized as much as it is the political control of, and material appropriation from, the periphery for the benefit of the metropole.

The CSAWP is a colonial creation in both senses of this definition. In the material sense, it facilitates the taking of labour power from Jamaica to intensify capital accumulation on Canadian farms. But it is also a tool to discipline rural Jamaicans into "respectable subjects" embodying metropolitan ideals of work, family and civil society. It is an expression of interlocking colonial relationships between Canada and Jamaica and the Jamaican government and its citizens, articulated at both levels through the language and rationality of the development project.

The problem of creating "respectable subjects" out of rural Jamaicans is rooted in post-emancipation discourses about free labour and the moral degeneracy of the 
freedpeople. The abundance of cultivable land in the interior and slaves' prior experience with subsistence farming created serious challenges for planters, missionaries and colonial officials who hoped that wages would replace coercion in providing labour for sugar plantations. The reluctance of free peasants to continue working the estates, and the refusal of colonial officials to encourage the peasant economy, led to economic decline in the 1840s and 50s and the emergence of the 'Quashee' stereotype: the lazy, feckless, licentious Afro-Jamaican morally unsuited to European civil society and a blight on the economic fortunes of the colony. After peasant farmers rose up in Morant Bay in 1865 , they also became perceived as potential threats to the life and property. These discourses would re-emerge periodically in times of social and economic unrest, through debates over birth control or urban squatting.

The free labour ideology that drove the Emancipation experiment in the $1840 \mathrm{~s}$ saw wage labour and the nuclear family as key tools to encourage the freedpeople to embrace Christian morality, accumulate capital and become 'civilized'. As such, employment was central to Jamaican strategies to manage social unrest and Europeanize its unruly poor. The institutionalized migration programs of the OEP originated in times of social crisis when jobs were scarce and regular migratory channels were closed.

In the modern era, the biopolitical, social scientific rationality of 'national development' has replaced colonial appeals to civilizational superiority, but the familiar 'Quashee' stereotype, concerns about 'surplus population', rural underdevelopment and social unrest remain ingrained in the social planning documents of the modern state. These stereotypes find expression in the various government interventions in the lives of CSAWP participants, potential participants, and rural communities at large. The 
programme screening criteria requires current and prospective workers to police their sexual behaviour, interactions with the law, encourages them to develop themselves as stocks of 'human capital' and discourages rural-urban migration. The highly politicized distribution of farm work tickets creates clientelist networks that encourage community policing. The Family Services Unit and the compulsory savings program encourage workers to take more responsibility for the material needs of their families, and occasionally makes determinations about workers' family ties. The cumulative result of these interventions is the production of "respectable subjects" adhering to coloniallyderived standards of behaviour.

As the recipient of Jamaican migrant labour, Canada acts both as neocolonial benefactor and developmentalist role model. Canada and Jamaica's relative positions and power relations within the international 'development' hierarchy are determined by their previous roles and positions within the British imperial system. The decision to admit workers from Jamaica, and the Anglo-Caribbean more generally, was a part of the Canadian assumption of British imperial responsibilities in the Caribbean in the 1960s. The inclusion of migration, particularly the promise of an expanded CSAWP, in the "aid and trade" agenda of the 1966 Caribbean Commonwealth-Canada Conference demonstrates how temporary foreign work programs fit in the development project Canada undertook in the Anglo-Caribbean. The establishment of preferential sugar tariffs and the expansion of migration channels each reflected the provision to Caribbean governments of tools to manage their 'surplus populations'. In both cases, Canada was extending management tools that Britain had either relinquished or was in the process of relinquishing. 
While the origins of the CSAWP can be partly explained as an avenue of colonial patronage, more recent developments in Canada's temporary foreign work programs require us to nuance that explanation. Mexico's share of workers under the program has steadily increased since they were admitted in 1974; they now send roughly twice as many workers as Jamaica. ${ }^{399}$ Canada's agricultural labour pool has further diversified through the Low Skill Pilot Program, through which workers can be procured from any country, although the number of CSAWP workers dwarfs the number of LSPP workers employed in agri-foods (29000 to 6000 in 2011, respectively). ${ }^{400}$

This international diversity suggests changes to the neocolonial paternalism Canada once cultivated in the Anglo-Caribbean. As Macdonald points out, the debt crisis of the 1980s rationalized bilateral aid regimes through the prescriptive influence of the IMF. $^{401}$ The waning of imperial preferences in migration programs may be attributable to this multilateral rationalization of the development project. It may also partially explain why Jamaica, despite its long history of managing migration programs, has entered a policy process with the International Organization on Migration (IOM) ${ }^{402}$

But the changing character of migration programmes does not necessarily mean the end of the colonial relations that underpin them. The changing place of CSAWP in Canada's, and Jamaica's, labour strategies and national development projects has much to

399 Macdonald and Gabriel: 49.

${ }^{400}$ Human Resources and Skills Development Canada website, "Temporary Foreign Work Program: Labour Market Opinion (LMO) Statistics, 2008-2011, http://www.hrsdc.gc.ca/eng/workplaceskills/foreign workers/stats/annual/table10aa.shtml\#CA , last accessed September 25, 2012.

${ }^{401}$ Macdonald: 134.

402 International Organization on Migration website, http://www.iom.int/jahia/Jahia/media/press-briefingnotes/pbnAM/cache/offonce/lang/en?entryld=29619 last accessed August 22, 2012. 
tell us about the unfolding of capitalism, the development project, and its relationship to

empire.

Shortly after my research trip was booked, a snap election was called in Jamaica which seriously curtailed access to public servants through their Parliamentary gatekeepers. This exacerbated the obstacles of an already opaque and tightly-controlled public service. My enquiries to the Labour Ministry's records management officer were turned down on "beacuse the Freedom of Information Act did not allow their release to me." A similar request to the Ministry of Foreign Affairs went completely unanswered. Contact information for the Labour Ministry is tightly managed from the top; phone numbers and emails for all but the top echelons are not publicly available. My requests for interviews with Labour civil servants had to pass through the Director of Manpower Services, who initially agreed to provide access but later declined, explaining only that the Permanent Secretary was "reviewing my request." I was told, thirdhand, that the government is concerned about the program being shut down, which has further heightened their suspicion of Canadian researchers asking prying questions. Given recent announcements by the Canadian government on changes to temporary foreign work programs and Employment Insurance, Jamaican fears are perhaps warranted.

ii Emancipation occurred piecemeal, dictated by the metropolitan powers that controlled the islands. Haiti notwithstanding, the British colonies were the first to free their slaves in 1834. The last Caribbean emancipation came in Cuba, in 1886 (see Mintz: 47).

iii Specifically: Jamaica, Trinidad and Tobago, Guyana, Antigua, Bahamas, Barbados, British Honduras, Dominica, Grenada, Montserrat, St. Kitts-Nevis-Anguilla, St. Lucia, St. Vincent. The UK and the University of the West Indies also sent observers.

iv Jack Pickersgill, Minister of Transport under Pearson.

$\checkmark$ The Assisted Passage Loan Scheme (APLS) was a program to provide interest-free loans to approved immigrants from Europe, to help them meet the costs involved in travelling to Canada. Loans would be repaid to the government over a two-year term. The program was initiated in 1951. (see: DFAIT, Cabinet Document No. 228-55, "Financial Measures to Assist Immigration," http://www.dfaitmaeci.gc.ca/department/history/dcer/details-en.asp?intRefld=1578.) 


\title{
Bibliography
}

\section{PRIMARY SOURCES}

\author{
Archival Sources: Library and Archives Canada, Ottawa
}

Department of Foreign Affairs Files: Record Group 25

'Political Affairs - Organizations and Conferences - Commonwealth Caribbean Canada Conference' vol 9123, file 20-4-CCCC-1 pt 1

'Political Affairs - Organizations and Conferences - Commonwealth Caribbean Canada Conference' vol. 9122, file 20-4-CCCC-1 pt 2

Lester Pearson Papers: MG 26 'Speeches, July 1966' N9, vol 40

\section{Canadian websites}

Foreign Agricultural Resource Management Services, http://www.farmsontario.ca/index.php, last accessed August 15, 2012.

Human Resources and Skills Development Canada, http://www.hrsdc.gc.ca, last accessed September 25, 2012

\section{Official Government of Canada Reports}

Citizenship and Immigration Canada, Canada Facts and Figures: Immigration Overview 2010, Citizenship and Immigration Canada, 2010.

\section{Government of Jamaica websites}

Bank of Jamaica, http://www.boj.org.jm/, last accessed July 9, 2012.

Jamaica Ministry of Labour and Social Security, http://www.mlss.gov.jm/pub/index.php?artid=1\&par $\mathrm{id}=1$ last accessed July 12, 2012.

Parliament of Jamaica, http://www.japarliament.gov.jm, last accessed July 18, 2012.

Planning Institute of Jamaica Website, http://www.pioj.gov.jm/, last accessed August 1, 2012. 


\section{Official Government of Jamaica Reports}

Jamaica Auditor General's Department, Report on the Appropriation and Other Accounts of Jamaica For the Financial Year Ended March 31, 2010 Kingston, Jamaica: Auditor General's Department, 2010.

Planning Institute of Jamaica; Vision 2030: Jamaica National Development Plan, Kingston, Jamaica: Pear Tree Press, 2009.

\section{Newspapers}

The Daily Gleaner, Kingston, Jamaica.

The Jamaica Observer, Kingston, Jamaica.

\section{Interview Data}

Interview with 'Keith', December 2011, Ocho Rios, Jamaica. Interview with 'David', December 2011, Kingston, Jamaica. Interview with 'Bruce', December 2011, Kingston, Jamaica.

\section{Contemporary Primary Accounts}

Merivale, Herman; Lectures on Colonization and Colonies, New York: Augustus M. Kelly, 1967 [1861].

Underhill, Edward; "A Letter Addressed to the Rt. Honorable E. Cardwell With Illustrative Documents on the Condition of Jamaica and an Explanatory Statement," London: Arthur Miall, 1866.

\section{SECONDARY SOURCES}

André, Irving; "The Genesis and Persistence of the Commonwealth Caribbean Seasonal Agricultural Workers Program in Canada", Osgoode Hall Law Journal 1990, 28(2): 243-301. 
Austin, Diane; "Culture and Ideology in the English-Speaking Caribbean: The View From Jamaica" American Ethnologist 1983, 10(2): 223-240.

Basok, Tanya; Tortillas and Tomatoes: Transmigrant Mexican Harvesters in Canada, Montreal and Kingston: McGill University Press, 2002.

Basok, Tanya; "Post-national Citizenship, Social Exclusion and Migrants Rights: Mexican Seasonal Workers in Canada" Citizenship Studies 2004, 8(1): 47-64.

Bauder, Harald; "Foreign Farm Workers in Ontario (Canada): Exclusionary Discourse in the Newsprint Media" Journal of Peasant Studies 2008 35(1): 100-118.

Binford, Leigh; "From Fields of Power to Fields of Sweat: The Dual Process of Constructing Temporary Migrant Labour in Mexico and Canada" Third World Quarterly 2009, 30(3): 503-517.

Bogues, Anthony; "Politics, Nation and Postcolony: Caribbean Inflections" Small Axe, March 2002: 1-30.

Bourbonnais, Nicole; "'Dangerously Large': The 1939 Labor Rebellion and the Debate Over Birth Control in Jamaica" New West Indian Guide 2009, 83(1\&2): 39-69.

Brem, Maxwell; "Migrant Workers in Canada: A Review of the Seasonal Agricultural Workers Program" Ottawa: North-South Institute, 2006.

Cecil, R.G. and G.E. Ebanks; "The Caribbean Migrant Farm Worker Programme in Ontario: Seasonal Expansion of West Indian Economic Spaces" International Migration 1992, 30(1): 19-37.

Clarke, Colin A(ed); Caribbean Social Relations University of Liverpool Monograph Series 8, 1978.

Cooper, Frederick, Thomas C. Holt and Rebecca J. Scott (eds); Beyond Slavery:

Explorations of Race, Labor and Citizenship in Postemancipation Societies, Chapel Hill: University of North Carolina Press, 2000.

Dean, Mitchell; Governmentality: Power and Rule in Modern Society, London: Sage, 2010.

Donaghy, Greg and Bruce Muirhead; "'Interests but No Foreign Policy': Canada and the Commonwealth Caribbean, 1941-1966" American Review of Canadian Studies 2008, 38(3): 275-294.

Fanon, Frantz; Black Skin, White Masks, New York: Grove Press, 2008 [1952].

Fanon, Frantz; The Wretched of the Earth, New York: Grove Press, 2004 [1963]. 
Foucault, Michel; Society Must Be Defended, New York: Picador, 2003.

Foucault, Michel; Discipline and Punish: The Birth of the Prison, New York: Vintage, 1995 [1977].

Gammage, Sarah; "Exporting People, Recruiting Remittances: A Development Strategy for El Salvador?" Latin American Perspectives 2006, 33: 75-100.

Garner, Steve; Guyana 1838-1985: Ethnicity, Class \& Gender, Kingston: Ian Randall Publishers, 2008.

Gray, Obika; "Predatory Politics and the Political Impasse in Jamaica" Small Axe 2003, 13: 72-94.

Hahamovitch, Cindy; No Man's Land: Jamaican Guestworkers in America and the Global History of Deportable Labour, Princeton, NJ: Princeton University Press, 2011.

Hintzen, Percy; "Reproducing Domination and Legitimacy Constructs in the West Indies" Social Identities: Journal for the Study of Race, Nation and Culture 1997, 3(1): 47-76.

Kamugisha, Aaron; "The Coloniality of Citizenship in the Contemporary Anglophone Caribbean" Race \& Class 2007, 49(2): 20-40.

Larkin, Sherrie; "Workin' on the Contract: St Lucian Farmworkers in Ontario, A Study of International Labour Migration" PhD dissertation, McMaster University, 1998.

McLaughlin, Janet; "Classifying the 'Ideal Migrant Worker': Mexican and Jamaican Transnational Farmworkers in Canada" Focaal--Journal of Global and Historical Anthropology 57 (2010): 79-94.

Macdonald, Laura; "Unequal Partnerships: The Politics of Canada's Relations with the Third World" Studies in Political Economy 1995, 47: 111-141.

Macdonald, Laura and Christina Gabriel; "Citizenship at the Margins: The Canadian Seasonal Agricultural Worker Program and Civil Society Advocacy", Politics \& Policy 2011, 39(1): 46-67.

Mars, Perry and Alma H. Young (eds), Caribbean Labor and Politics: Legacies of Cheddi Jagan and Michael Manley, Detroit: Wayne State University Press, 2004.

Mintz, Sidney; Caribbean Transformations, Chicago: Aldine, 1974.

Opie, Frederick Douglass; Black Labour Migration in Caribbean Guatemala 1882-1923, Gainesville, FL: University Press of Florida, 2009.

Preibisch, Kerry; "Pick Your Own Labour: Migrant Workers and Flexibility in Canadian Agriculture"International Migration Review 2010, 44(2): 404-441. 
Preibisch, Kerry and Leigh Binford; "Interrogating Racialized Global Labour Supply: An Exploration of the Racial/National Replacement of Foreign Agricultural Workers in Canada", Canadian Review of Sociology and Anthropology 2007, 44(1): 5-36.

Preibisch, Kerry and Jenna Hennebry; "Temporary Migration, Chronic Effects: The Health of International Migrant Workers in Canada" Canadian Medical Association Journal 2011 183(9): 1033-1038.

Rodriguez, Robyn Magalit; Migrants for Export: How the Philippine State Brokers Labor to the World, Minneapolis: University of Minnesota Press, 2010.

Russell, Horace O.; "The Reactions of the Baptist Missionary Society and the Jamaican Baptist Union to the Morant Bay Revellion of 1865" Journal of Church and State 1993, 35(3): 593-603.

Said, Edward; Orientalism, New York: Vintage, 1979.

Satzewich, Vic; Racism and the Incorporation of Foreign Labour: Farm Labour Migration to Canada since 1945, New York: Routledge, 1991.

Satzewich, Vic; "Business or Bureaucratic Dominance in Immigration Policymaking in Canada: Why was Mexico Included in the Caribbean Seasonal Agricultural Workers Program in 1974?" International Migration \& Integration 2007, 8: 255-275.

Saunders Kay(ed); Indentured Labour in the British Empire 1834-1920, Beckenham, Kent: Croom Helm Ltd, 1984.

Scott, David; "Colonial Governmentality", Social Text 1995, 43: 191-220.

Scott, David; "Political Rationalities of the Jamaican Modern" Small Axe 2003, 7(2): $1-22$.

Schwarz, Henry and Sangeeta Ray (eds) A Companion to Postcolonial Studies, Malden, MA: Blackwell Publishing, 2005.

Sharma, Nandita; Home Economics: Nationalism and the Making of Migrant Workers in Canada Toronto: U of T Press, 2006.

Smith, Adrian A., "Legal Consciousness and Resistance in Caribbean Seasonal Agricultural Workers", Canadian Journal of Law and Society 2005, 20(2): 95-122.

Stasiulis, Daiva and Nira Yuval-Davis (eds); Unsettling Settler Societies: Articulations of Gender, Race, Ethnicity and Class, London: Sage, 1995.

Walters, William and Wendy Larner; "The Political Rationality of New Regionalism: 
Toward A Genealogy of the Region", Theory and Society 2002, 31(3): 391-432.

"Directory Jamaica: Country Profile", United Nations Department of Economic and Social Affairs, http://unpan1.un.org/intradoc/groups/public/documents/un/unpan027754.pdf, last accessed July 6, 2012. 